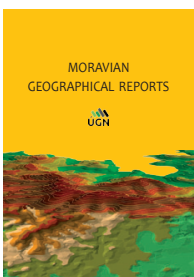

MORAVIAN GEOGRAPHICAL REPORTS

The Czech Academy of Sciences, Institute of Geonics

journal homepage: http://www.geonika.cz/mgr.html

doi: https://doi.org/10.2478/mgr-2021-0012

\title{
Suburbanisation processes within and outside the city: The development of intra-urban suburbs in Wrocław, Poland
}

\author{
Robert SZMYTKIE ${ }^{\text {a }}$
}

\begin{abstract}
:
The scale and the specificity of intra-urban suburbanisation is subject to evaluation in this article, based on a case study of Wroctaw city (SW Poland), using data on population changes at an intra-urban scale and on the level of construction activity in the city. Intra-urban suburbanisation is characterised by intensive construction activity and population growth in the peripheral districts of the city, while depopulation takes place in the central part of the city and in large panel block estates from the socialist period. The main factors for the development of intra-urban suburbanisation are a reaction to the unfavourable (from the perspective of the city) suburbanisation processes (outflow of residents and tax revenue, road traffic congestion and the necessity to service populations residing de facto outside the city). The existence of extensive non-urbanised areas within the larger cities of Central and Eastern Europe (identified as potential areas for investment) results from the specific nature of their territorial development in the 20th century, including incorporation processes connected with planned urbanisation.
\end{abstract}

Key words: intra-urban suburbs, residential suburbanisation, population changes, Wroctaw, Poland

Article history: Received 3 October 2019, Accepted 20 January 2021, Published 30 June 2021

\section{Introduction}

One of the most noticeable socio-economic processes in the post-socialist countries of Central and Eastern Europe (CEE) is the suburbanisation occurring in the surroundings of large cities. This phenomenon has been extensively described in the literature. Publications on suburbanisation in this part of Europe may be assigned to six main subjects (see Kubeš, 2013): 1) the physical spatial structure of the city and its transformations; 2) the functional spatial structure of the city and its transformation; 3) the housing structure in urban neighbourhoods in connection with changes in housing policy and the market; 4) the social spatial structure of the city and its transformation; 5) suburbanisation and urban sprawl in the near hinterland of city; and 6) urban planning and management on city territory.

Increased interest in the phenomenon of suburbanisation in post-socialist countries results primarily from the scale and dynamics of the process itself, which to some extent served to make up some of the delays about similar processes observed in Western European countries, largely over the whole post-war period (Brezdeń and Szmytkie, 2019). Thus, it may be said that in the period the development and scale of suburbanisation in Europe was strongly dependent on the political system and level of socio-economic development of individual countries, and the Iron Curtain turned out to be a barrier to the expansion of this phenomenon (Pacione, 2001; Schneider-Sliwa, 2006).

Inter alia, the political transformation of the 1990s and the connected socio-economic changes (market-oriented growth) permitted the development of residential construction and the fulfilment of citizens' individual needs, which had been stifled in the preceding period (Schneider-Sliwa, 2006; Leetmaa et al., 2009; Kubeš, 2013). The central planning system during the socialist period, with its focus on industrialisation and urbanisation, was an impediment to the development of such processes. Moreover, up to 1989, a significant part of migration was attributed to official government policies that promoted the growth of larger cities and towns to provide the necessary industrial labour force (Dawson, 1987; Sailer-Fliege, 1999, Pacione, 2001). Thus, in the post-socialist countries of CEE, the dynamic processes of urban sprawl into suburban areas started only after almost a half a century's delay (Lechman, 2005). The second phase of suburbanisation in Central and Eastern Europe led to the rapid and uncontrolled spatial growth of cities and the development of suburban zones, which was accompanied by a decline in the population in city centres and

\footnotetext{
${ }^{a}$ Institute of Geography and Regional Development, University of Wrocław, Wrocław, Poland (*corresponding author: R. Szmytkie, e-mail: robert.szmytkie@uwr.edu.pl)
} 
migration to the suburbs (Wecławowicz, 1997; Sýkora, 1999; Lowe and Tsenkova, 2003; Hamilton et al., 2005; Nuissl and Rink, 2005, Schneider-Sliwa, 2006; Hirt and Stanilov, 2007; Martyniuk et al., 2016). In comparison, suburbanisation in this paper is understood as a stage of urban development which occurs when the inner ring or commuter belt grows at the expense of the urban core, compared to urban sprawl which is a specific morphological form of suburbanisation connected with the spread of a city into suburban areas, often without planning (see Pacione, 2001; Caves, 2005; Knox and Mc Carthy, 2005).

Research on construction activity in Wrocław (Namyślak and Sikorski, 2010; Ciok, 2017) and other large cities in Poland (Śleszyński, 2005; Kotus, 2006; Marcińczak, 2012; Stępniak and Mendel, 2013; Spórna, 2018; Szafrańska et al., 2019) indicates the presence of intensive activity not only in suburban zones, but also within large cities. Interestingly, intensive construction activity within the boundaries of large cities does not correspond to a growth of population there, at least according to official statistical data (Śleszyński, 2005; Gałka and Warych-Juras, 2018). Moreover, there are considerable differences within city space with respect to population changes, which is manifested in the decline of population in central parts, as well as growth of population in peripheral districts of the city (Spórna, 2018; Szafrańska et al., 2019), contributing to, among others, changes in population density profiles (Śleszyński, 2014). Similar processes are also observed within the administrative borders of large cities in other CEE countries (see Sýkora and Čermák, 1998; Soós and Ignits, 2003; Ira, 2003; Tosics, 2006; Banzhaf et al., 2007; Steinführer and Haase, 2007; Sýkora and Ouředníček, 2007; Wiechmann, 2008; Brade et al., 2009; Haase and Rink, 2015; Holm et al., 2015). This process can be called intra-urban suburbanisation (compare Lisowski and Grochowski, 2009; Spórna and Krzysztofik, 2020). The attention of researchers focuses primarily on 'proper' suburbanisation, and studies on intra-urban suburbanisation are very rare, especially those aimed at identifying the process itself and determining its scale and significance (see Spórna, 2018; Szafrańska et al., 2019; Spórna and Krzysztofik, 2020).

These general findings resulted in the proposed research hypothesis for this paper: for large cities in the post-socialist countries of Central and Eastern Europe, suburbanisation in suburban zones is accompanied by processes of intra-urban suburbanisation that have a similar character and intensity and occur in the peripheral and weakly urbanised districts of the city. Thus, the main objective of this study was to identify the processes of intra-urban suburbanisation based on a case study of Wrocław, using data on population changes on an intra-urban scale and on the scale of construction activity. An identification of intra-urban suburbanisation will demonstrate the complexity of socio-economic changes taking place within the city (between central and peripheral areas), and at the same time, will indicate that urban sprawl can occur not only outside the city (Champion, 2001; Bruegmann, 2006; Mace, 2009; Harris, 2010; Forsyth, 2012), but also within its administrative borders. To supplement the main objective of this study, research questions are asked concerning:

1. What is the scale and intensity of intra-urban suburbanisation compared to similar processes observed in the suburban zone;
2. What are the features of morphological changes caused by intensive construction activity in the peripheral districts of the city;

3. What are the population structures and demographic characteristics of the multi-family housing estates ${ }^{1}$ and residential districts forming the intra-urban suburbs within the city;

4. Is there the difference between the real population of the city and population recorded in official statistics; and

5. What are the determinants of intra-urban suburbanisation in the larger cities of Central and Eastern European countries.

\section{Theoretical background}

In Western European countries a modern (second) phase of suburbanisation started in the 1960s, while in Central and Eastern Europe this process occurred only to a limited extent (see Tammaru, 2001; Logan, 2019). The problem in these latter countries was obtaining building loans, building plots, various official permits, building companies, craftsmen, and building materials (Kubeš, 2013). In the 1990s, however, the deregulation of development and housing policies in postsocialist countries also resulted in considerable momentum in the transformation of large cities and functional urban areas (Sailer-Fliege, 1999). In doing so, the respective development and housing policies influenced the scale and form of city-to-suburb migration (Brade et al., 2009). Like most of the reforms initiated after the collapse of the socialist system, housing reforms carried out during the 1990s by CEE countries were strongly influenced by the desire to find a radically different approach to housing, negating the principles of the former socialist system. Under these circumstances, privatisation, deregulation and cuts in state funding became the three main principles of housing reform (Hirt and Stanilov, 2007). Other factors of postsocialist urban transformation were the re-establishment of local self-government and urban planning, the return of land rent, an increase in housing costs, and the promotion of private or social rented housing (Sailer-Fliege, 1999). The first decade of transition in the 1990s was characterised by inflows of investment into city centres, especially in the early-reforming countries, triggering a decline in their residential function amidst substantial commercialisation and physical upgrading. This was followed by a process of decentralisation, as investments flowed to both out-of-centre and suburban locations (Sýkora and Ouředníček, 2007).

Residential suburbanisation is the relocation of the population from the core city to new housing developments in the suburban zone. It has a dual impact on both the target localities (suburbs) and sources of migration (inner city, large housing estates from socialist period) (Ouředníček, 2007). Residential suburbanisation contributes the spatial deconcentration of housing developments and changes in the number and density of the population (Spórna and Krzysztofik, 2020). The process of suburbanisation is connected to the development of new settlement structures in the suburban zone of a city. New developing areas might be concentrated around the compact town, but also individually scattered in many small localities and rural settlements in the wider surroundings of a city. Thus it is a development of residential and commercial areas at the expense of agriculture

\footnotetext{
${ }^{1}$ Housing estate is an area containing a large number of houses or apartments built close together at the same time (dictionary. cambridge.org).
} 
or unused land (greenfields). New residential districts and reconstructed village properties are accompanied by shopping centres, warehousing and industrial zones (Sýkora, 1999; Matlovič and Sedláková, 2007).

From a morphological point of view, suburbanisation is connected with the process of selective or even the so-called leap-frog development (Matlovič and Sedláková, 2007). Mantey and Sudra (2019) distinguished 16 types of residential suburbs in post-socialist countries, which shows the complexity of suburban sprawl there. An important factor stimulating suburban development is the lower cost of land and, from the developers' point of view, undemanding project approval requirements of local self-government authorities (Sýkora, 2001). Some other important factors that determine the processes of suburbanisation are changes in value orientations concerning the residences of upper middle-class households, and the development of individual motorisation (Matlovič and Sedláková, 2007), so that, accessibility to roads promotes sprawl and influences the development of cities (Baum-Snow, 2007; Garcia-López et al., 2015).

During the socialist period, the new subsidised and standardised apartments in the cities were a relatively highly valued segment of the housing market (Rykiel, 1984), and they tended to be inhabited by people with higher social status (Kulu, 2003). In contrast, unsubsidised single-family houses in the suburbs often lacked modern facilities and housed the urban workforce, who did not have access to urban housing because they worked in non-priority sector enterprises (Andrusz et al., 1996). Since 1989, suburban communities in Poland emerged largely at random and included two types of residents: (a) affluent families that wished to have more space and amenities than what cooperative housing in large cities could offer; (b) middle-class citizens who built their own homes using their personal savings and the help of friends and family (Zebik, 2011). Suburbanisation has become one of the most visible features of the process of spatial restructuring, rearranging the urban patterns of the postsocialist city (Leetmaa et al., 2009). In part, this is because deconcentration of the population results from the growing popularity of environmental reasons for migration. Kontuly and Geyer (2003) asserted that poor people tend to migrate to stronger economic centres (supporting urbanisation), while wealthier people prefer the environmental quality of smaller settlements (supporting counter- or suburbanisation). Another important social factor determining the progress of suburbanisation is the change in the lifestyle of urban residents and the desire to live in a house with a private yard - the famed 'American Dream' (Beauregard, 2006).

On the regional scale, suburbanisation is manifested in depopulation or population stagnation in the agglomeration core (core city) and in a growth of population in its suburban zone, which is caused mainly by an inflow of migrants from the city (Musil, 1993; Sýkora, 1999; Timar and Varadi, 2001; Hamilton et al., 2005; Śleszyński, 2005; Bruegmann, 2006; Schneider-Sliwa, 2006; Sýkora and Ouředníček, 2007; Hirt and Stanilov, 2009; Sýkora and Bouzarovski, 2012; Schmidt et al., 2015; Mantey and Sudra, 2018). Research on changes in intra-urban spatial structures conducted in large urban agglomerations of Central and Eastern Europe have shown such tendencies:

- in the case of Prague: decline of the population in most areas in the inner city and increase of the population in the majority of suburban boroughs and municipalities (outside the compact city); the growth of population is concentrated in areas with the best natural environment and good transport accessibility (Sýkora and Ouředníček, 2007), while a considerable amount of post-1989 single-family detached housing can be found within the outer band of the territory of the city (16.7\%) (Stanilov and Sýkora, 2012);

- in Budapest: the rate of urban expansion in the core city was $7.6 \%$, which concerned peripheral areas located near the administrative borders of the city (Kovács et al., 2019);

- for the Katowice conurbation: depopulation processes in the downtown areas of cities and in areas with dominant multi-storey buildings from the socialist period (constructed from pre-fabricated elements), and growth in the number of inhabitants in several zones, including: the surroundings of the most invested-in areas of cities (city centres), but still within their administrative borders, including the city borders with surrounding rural areas; unused areas in the close vicinity to city centres, and polycentric areas of wasteland (postindustrial areas, post-agricultural areas) (Spórna, 2018); construction traffic in the Katowice conurbation in the years 2000-2017 indicates the initiation and development of 'classic' suburbanisation processes in the outer zone of the agglomeration, and of 'inner' suburbanisation in the conurbation core (Spórna and Krzysztofik, 2020);

- in the case of Łódź: population loss in areas with a high percentage of low quality, standard, old housing resources and areas of blocks of flats built in the 1950s and 1960s, and population increase in new residential areas in the outer zones of the city, which is the result of the outward migration to newly-built, detached single-family houses (Szafrańska et al., 2019);

- finally, for Warsaw: intensive construction activity in the peripheral districts of the city; these sub-central and peripheral investments were often large-scale residential districts that consumed large amounts of land, often including internal road infrastructure on a private estate that locked out outsiders and has no connection to its immediate surroundings (Stępniak and Mendel, 2013).

In Poland, as a result of the significant territorial expansion of large cities during the socialist period (Szymańska et al., 2009, Szmytkie and Krzysztofik, 2019), city limits encompass former suburbs as well as large swaths of undeveloped land. This creates a fundamental problem when attempting to define 'the suburbs' in Poland (Zębik, 2011): peripheral zones of large cities in which growth in population and intensive construction activity occurred, are called 'inner city' suburban zones (Spórna, 2018) or the inner suburbs (Szafrańska et al., 2019, Spórna and Krzysztofik, 2020) in the literature. Some similar terms, 'inner suburb' or 'inner-ring suburb', may be found in British and American literature on the subject (Hanlon, 2010). Such developments, however, mainly refer to suburban areas that existed in the Victorian era and to inter-war suburbanisation. These suburbs, formed of semi-detached houses, were established in the immediate vicinity of the cities, forming their outer ring (Frey et al., 2006; Mace, 2009) and, in the course of the territorial development of the city, have become their most inherent parts (Whitehand and Carr, 2001). The dynamic territorial expansion of cities in the $19^{\text {th }}$ and $20^{\text {th }}$ century, by incorporation of the surrounding areas (formal extension of city boundaries), which was typical for CEE cities, contributed to the formation of 'suburbs within the city' (Jindrich, 2012; Szmytkie, 2019; Szmytkie and Krzysztofik, 2019). 
According to Spórna and Krzysztofik (2020), intra-urban suburbanisation may be interpreted in two ways: 1) as the growth of single-family housing estates (by individuals and by property developers) within formal city limits; or 2) such development may be identified within the real urbanised (core) area of a city or urban agglomeration. In the first case, 'inner' city suburbanisation has the characteristics of 'classical' suburbanisation that occurs within formally drawn city boundaries. In the second case, inner suburbs are identified as an enclave of low-rise buildings located in the surroundings of an existing urbanised area of a town. In the case of neighbouring towns, 'inner' suburbanisation develops between urbanised zones shaped in both urban centres and is closely connected to the occurrence of nonurbanised areas.

In this study, due to the different (monocentric) spatial structure of the Wrocław agglomeration and the character of the territorial expansion of the city (see Szmytkie, 2019), intraurban suburbanisation is understood as the development of peripheral zones of the city, associated with the influx of migrants to the area and intense construction activity.

In such an interpretation, the process of intra-urban suburbanisation involves movements of the population in the search of more comfortable residential conditions, and the migrations have an internal character, i.e. they occur within the administrative borders of the city. The target of intra-urban migration is usually areas that are free from any investments (greenfields) (Koman, 2017). An increase in population density in these areas derives from new housing investments, both private and constructed by developers (Spórna, 2018). Housing construction in the area of intraurban suburbs is spontaneous, uncontrolled and focused on greenfield areas (agriculture land), often unrelated to the existing development, similar to classic suburbanisation occurring outside the city. According to Spórna and Krzysztofik (2020), two conditions distinguish such intraurban suburbanisation from typical suburbanisation or reurbanisation: 1) the location of new residential investments (within the administrative boundaries of a city and on already urbanised areas or between them); and 2) the physiognomy of the new developments (detached, semidetached and terraced housing). A separate factor that distinguishes intra-urban suburbanisation results from the issue of retaining the population within the city borders (in that the local scale migration is internal not external or outside the city), and the direction of migration (from the city centre to its periphery).

\section{Data and methods}

The research procedures adopted for the needs of this study may be divided into several key stages, differing with respect to the level of detail of the analyses conducted. The initial stage of research included identification of the (sub)urbanisation processes around Wrocław, which in the post-war period was subject to processes typical for cities in post-socialist countries of CEE (urbanisation and industrialisation in the socialist period until 1989, and suburbanisation in the post-socialist period). This analysis places a particular focus on investigating the trends in population changes typical for both sub-periods distinguished, occurring in Wrocław and its suburban zone. At this stage of the research, official statistical data on population and basic factors of population change from Statistics Poland (natural change, migration) were used. The study area (the Wrocław agglomeration) was divided into three main parts:

1. The city (the core of the agglomeration and intra-urban suburbs);

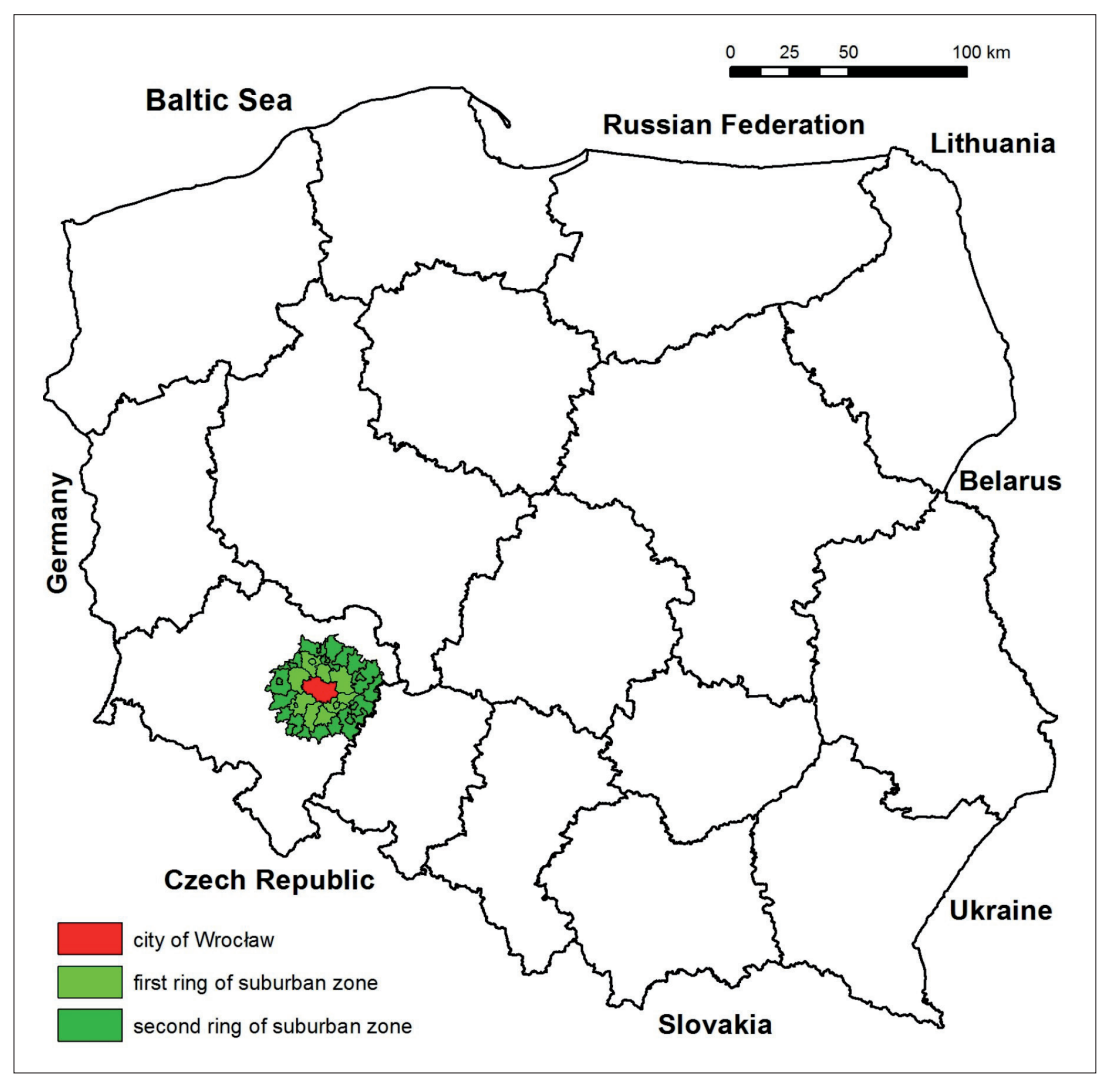

Fig. 1: Location of the Wroctaw Urban Region within Poland

Source: author's elaboration 
2. The first ring of municipalities covering units directly bordering the city; and

3. The second ring of municipalities covering the units directly bordering the first ring (see Fig. 1: Brezdeń and Szmytkie, 2019).

The second stage of the project involved the analysis of contemporary changes in population with respect to urban units (city districts) in Wrocław, for which data from the City Office in Wrocław for the years 2000-2016 were used. In this case, the time range of the analysis resulted from the availability of statistical data. This made it possible, however, to establish the differences in trends in population changes within city borders and to identify the phenomenon of intra-urban suburbanisation. To confirm the premise, data on construction activity in Wrocław (dwellings completed in the years 2000-2016), as well as an analysis of cartographic materials (topographic maps and satellite images from this period) were used, allowing the identification of morphological (spatial) changes that the peripheral districts of the city were currently undergoing. Peripheral districts include settlements incorporated into the city in the interwar and post-war period, as the city border from 1924 coincides with the compact urbanised area (urban core) (Szmytkie, 2019). The cartographic analysis included an identification of the character of the building development and its basic morphometric parameters, such as street layout, size of street blocks, size and distribution of plots, etc.
The last stage of this research project involved case studies. Its aim was to identify the population structure and demographic characteristics of residential districts constituting intra-urban suburbs within Wrocław, for which detailed address data from the PESEL ${ }^{2}$ database on population and structure by sex and age for the years 2000-2016 were used ${ }^{3}$. The data were obtained from the resources of the Ministry of Digitisation, and their time scope corresponds to the data provided by the City Office in Wrocław. The case studies were conducted in five selected residential estates located in the peripheral zone of the city and built in the years 2000-2010, representing typical forms of modern residential development in Wrocław. This study covered three examples of multi-family housing estates built by development companies: 1) the estate at Żernicka Street (Żerniki); 2) Jagodno; and 3) the Lawendowe and Cynamonowe estates (Lipa Piotrowska); one example of a communal multi-family housing estate built at the initiative of the municipal self-government: 4) the estate at Wojanowska Street (Stabłowice); and an example of an estate built by a development company with single-family housing: 5) the Malownicze estate (Marszowice) (Fig. 2). ${ }^{4}$

Moreover, in order to answer one of the research questions, a survey was conducted in the housing estate at Żernicka Street. The survey was carried out in June 2018 and its aim was to identify the actual number of people living in the estate, which made it possible to compare it with the

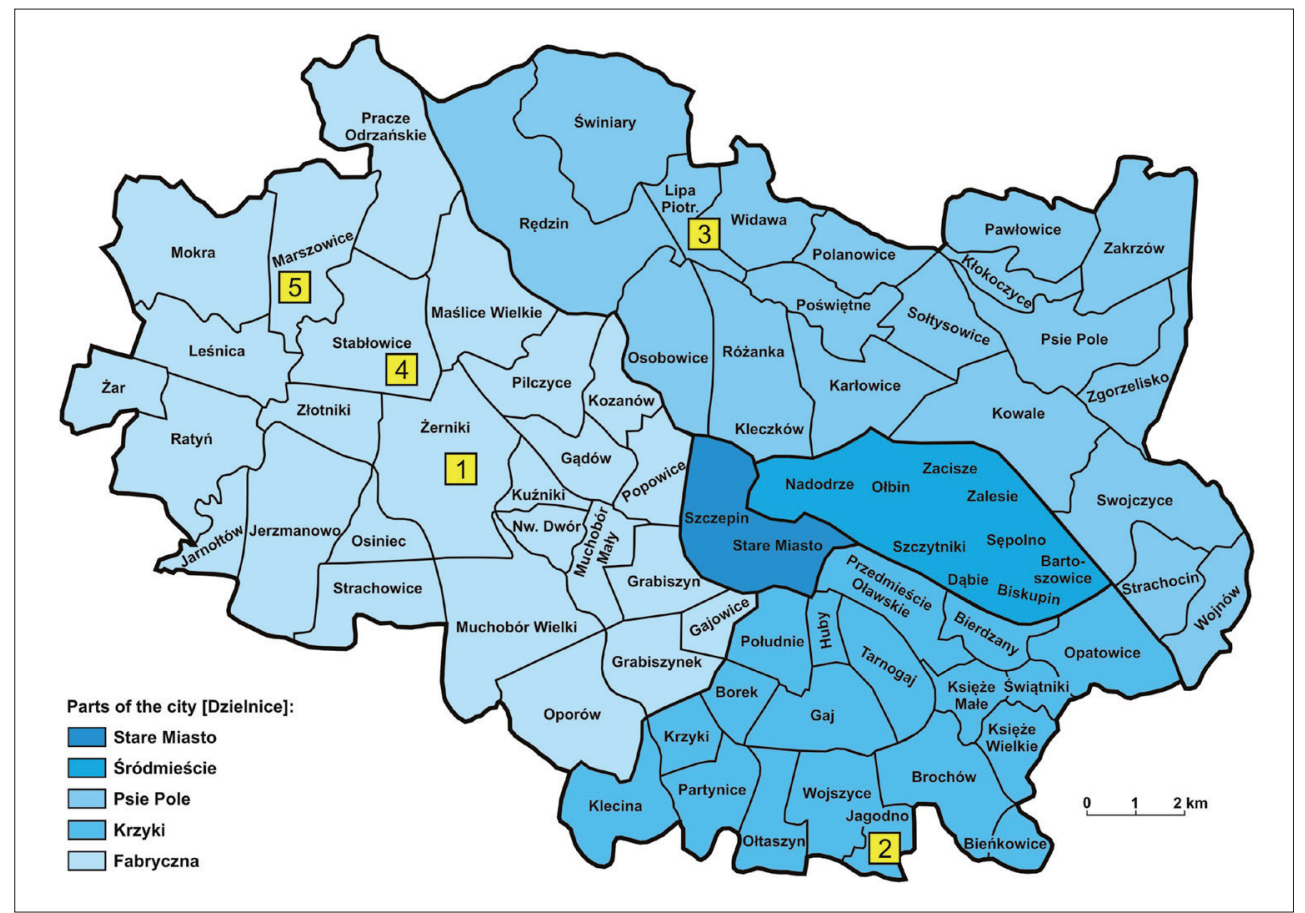

Fig. 2: Location of housing estates or residential districts mentioned in the text (Legend: 1 - the estate at Żernicka Street (Żerniki), 2 - Jagodno, 3 - the Lawendowe and Cynamonowe estates (Lipa Piotrowska), 4 - the estate at Wojanowska Street (Stabłowice), 5 - the Malownicze estate (Marszowice). Source: author's elaboration

\footnotetext{
${ }^{2}$ Universal Electronic System for Population Records (PESEL) is a central data set maintained in Poland by the minister responsible for computerisation under the Act on population registration. The register is used to collect basic information identifying the identity, administrative and legal status of Polish citizens and foreigners residing in the territory of the Republic of Poland.

${ }^{3}$ In the case of Poland, statistical data on an annual basis are published only for communes. Data on population for individual settlements or urban units (parts of cities) are published only on the basis of National Censuses or can be purchased from the PESEL database.

${ }^{4}$ Such a selection of housing estates was dictated by the specific nature of residential development in the intra-urban suburb zone in Wrocław, where multi-family housing estates built by development companies prevail, while in the suburban zone, singlefamily residential districts built by development companies dominate.
} 
number of people reported for this estate in official statistics. The surveys also touched on: education and occupation of estate residents, previous place of residence and factors that contributed to their moving to the estate. Sixty-five percent of the adult residents of the housing estate (70 people) took part in the survey. The questionnaires was distributed to all residents of the estate, however, not all of them returned the completed questionnaire to the given address.

\section{Results}

\subsection{Suburbanisation processes around Wrocław}

Wrocław is undergoing one of the most intensive suburbanisation processes in Poland (Śleszyński, 2006, 2013). The characteristics of suburbanisation as observed in Wrocław may be depicted as follows. The number of the residents of the city grew uninterruptedly after 1945 , which was caused by the planned industrialisation and urbanisation of the country, and achieved a maximum of population at the start of the period of socio-economic transformation (in the case of Wrocław this happened in 1991, when the city reached 643.6 thousand residents) (Książek and Suszczewicz, 2017). From this point on, according to official statistical data, the number of the residents of the city stabilised at the level of 630-640 thousand (Baginska and Szmytkie, 2005) and currently (2017), Wrocław is inhabited by 638.6 thousand persons. Until the start of the $21^{\text {st }}$ century, the suburban zone was characterised by a stable, slight growth of its population, caused in particular by positive natural growth. In 1980 the ring of communes surrounding Wrocław was inhabited by 98.0 thousand people, in 1990 , by 104.2 thousand and in 2000 , by 111.4 thousand. With the start of the $21^{\text {st }}$ century, the dynamics of population growth in the suburban zone accelerated significantly. In 2010 the communes around Wrocław were inhabited by 140.6 thousand, and in 2017 by 167.4 thousand. The main factor of population changes in the suburban zone is currently a positive balance of migration, which has been at a level of over $20.0 \%$ annually since 2006. Furthermore, the inflow of population to the suburban zone results in a rejuvenation of population structures and contributes to the stable growth of natural increase. In recent years also the demographic situation of Wrocław has improved, and is currently characterised by a positive balance of migration and natural increase (see Fig. 3). The dynamics of population change in suburban zone of Wrocław, however, is quite varied spatially (Fig. 4).

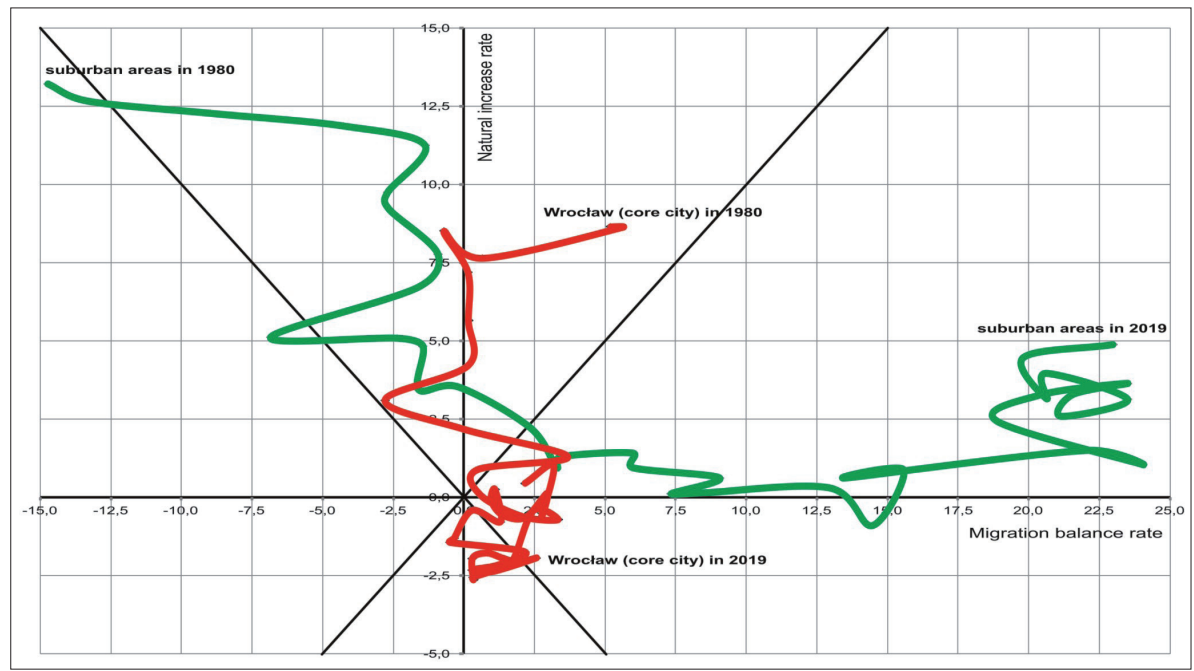

Fig. 3: Factors of population changes in Wroctaw and its suburban areas (1980-2017) Source: author's elaboration based on Local Data Bank (Statistics Poland)

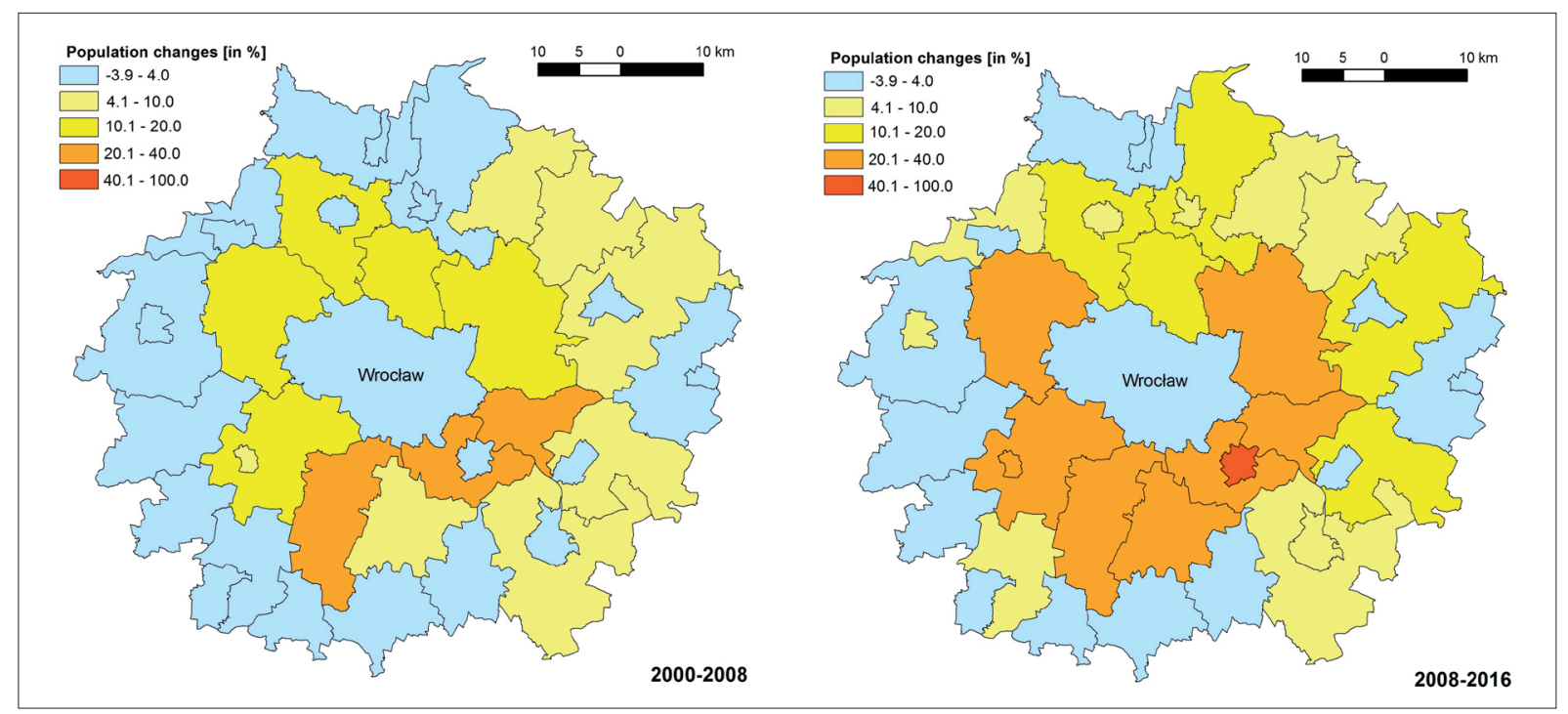

Fig. 4: Population changes in Wroctaw and its suburban areas (2000-2016)

Source: author's elaboration based on Local Data Bank (Statistics Poland) 
In the years 2000-2008, the greatest increase in population (over 20\%) occurred in communes neighbouring Wrocław to the SE, and in the remaining communes of the first ring the increase in resident numbers was at a level of 4 to $20 \%$. In total, in 2000-2008 the communes of the first ring recorded population growth of $14.7 \%$, and communes of the second ring, of $1.2 \%$. In the years 2008-2016 the increase of population was over $20 \%$ in practically all communes of the first ring. Moreover, the number of communes in the second ring which noted a significant increase in number of inhabitants (over 4\%) grew from 4 to 12 , which indicates an increasing growth rate of suburbanisation processes around Wrocław. In the years 2008-2016, the communes of the first ring recorded population growth of $27.1 \%$, and communes of the second ring $4.0 \%$. Analysis of population changes with respect to settlements in the years 1988-2011 additionally indicates a relationship between the scale of suburbanisation and transport accessibility (see Fig. 5). The highest population growth occurs in localities that are easily accessible from the city. This is clearly visible in Figure 6 representing the relationship between the change in population and distance needed to reach downtown Wrocław.

\subsection{Intra-urban suburbanisation in Wrocław}

In the case of Wrocław (as well as other large cities of Central and Eastern Europe), the claim that demographic development is stagnant does not reflect the real demographic situation in that area, as it is highly varied. Namely, an analysis of population changes with respect to urban units (city districts) in Wrocław for the period 2000 2016 indicates that in different parts of the city, different trends in demographic change were present (see Fig. 7).

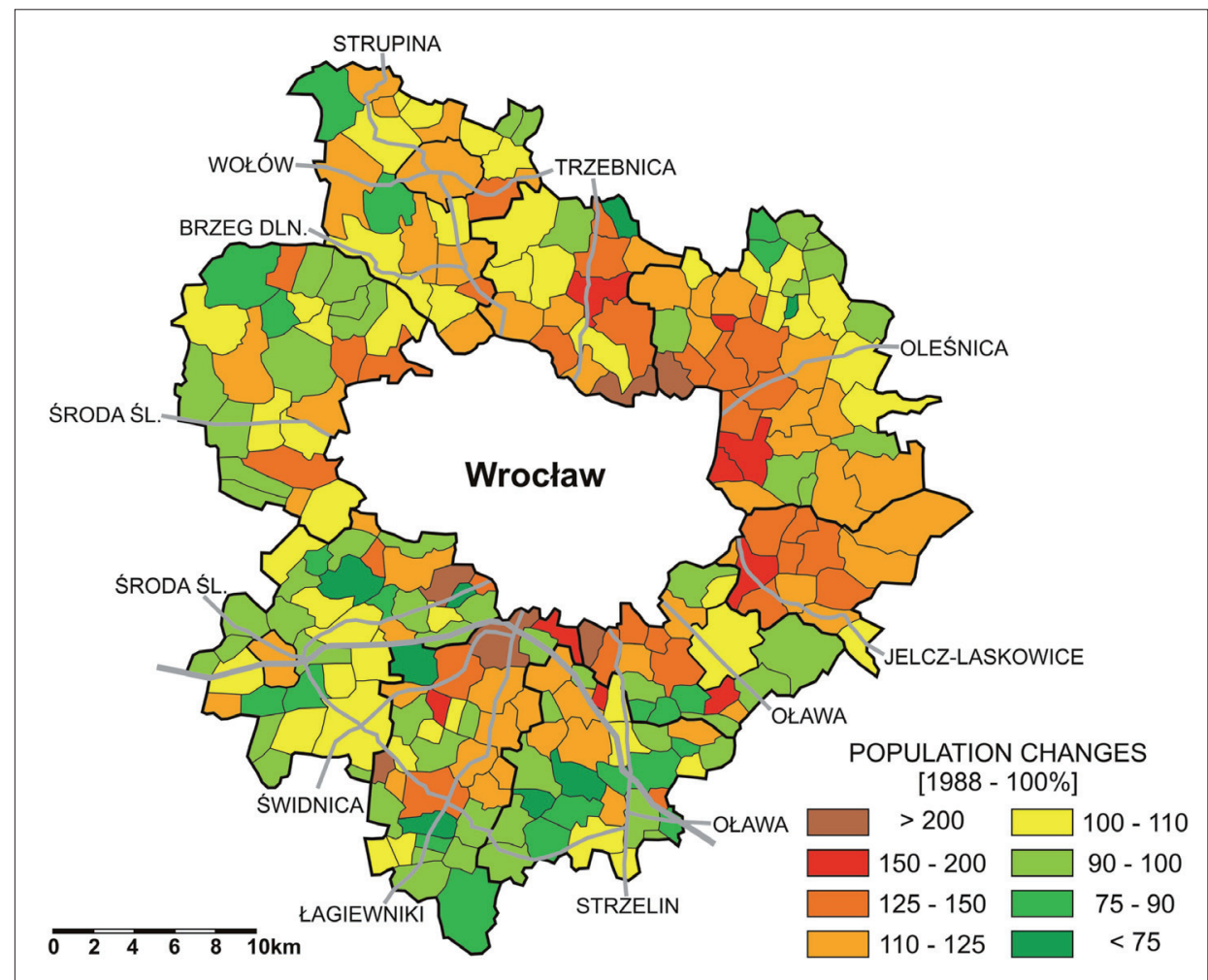

Fig. 5: Population changes in the settlements of the first ring of communes surrounding Wroctaw (1988-2016) Source: author's elaboration based on Local Data Bank (Statistics Poland)

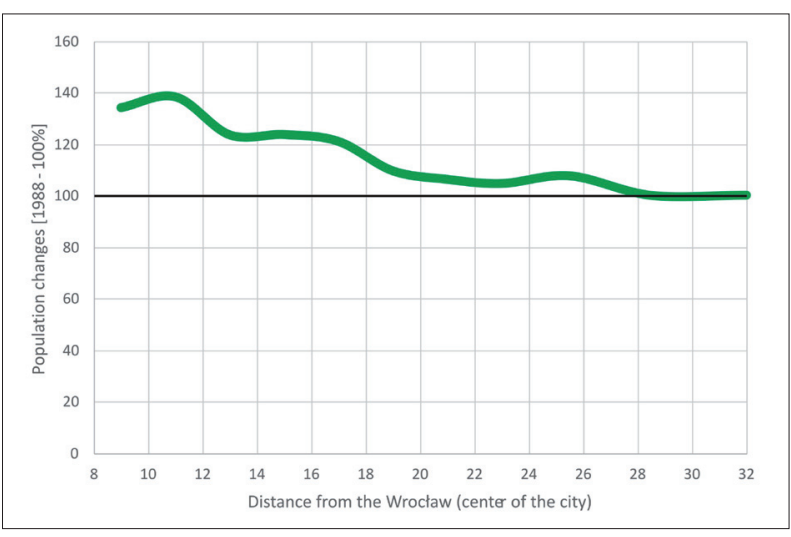

Fig. 6: Correlation between population changes in suburban areas of Wroctaw (1988-2016) and distance from the city centre

Source: author's elaboration based on Local Data Bank (Statistics Poland)
The central part of the city (Stare Miasto [Old City], Śródmieście [Downtown]), the districts surrounding the centre and the large panel block estates, are characterised by decline or stagnation of their populations, while in peripheral districts (southern, western and northern edges of the city) the number of residents is increasing. Furthermore, in the case of most districts of the city, the increase in population is constant, and its intensity is comparable with the increase in population observed in the first ring of communes in the suburban zone (Fig. 5). This kind of duality with respect to demographic changes within city borders contributes to significant changes in the distribution and structure of population in the relationship between the centre and peripheral districts of the city, and also to significant changes within city space, particularly as regards morphology.

In the case of spatial distribution, the process of population deconcentration is ongoing, involving a constant growth of population density in peripheral districts. Only in the 


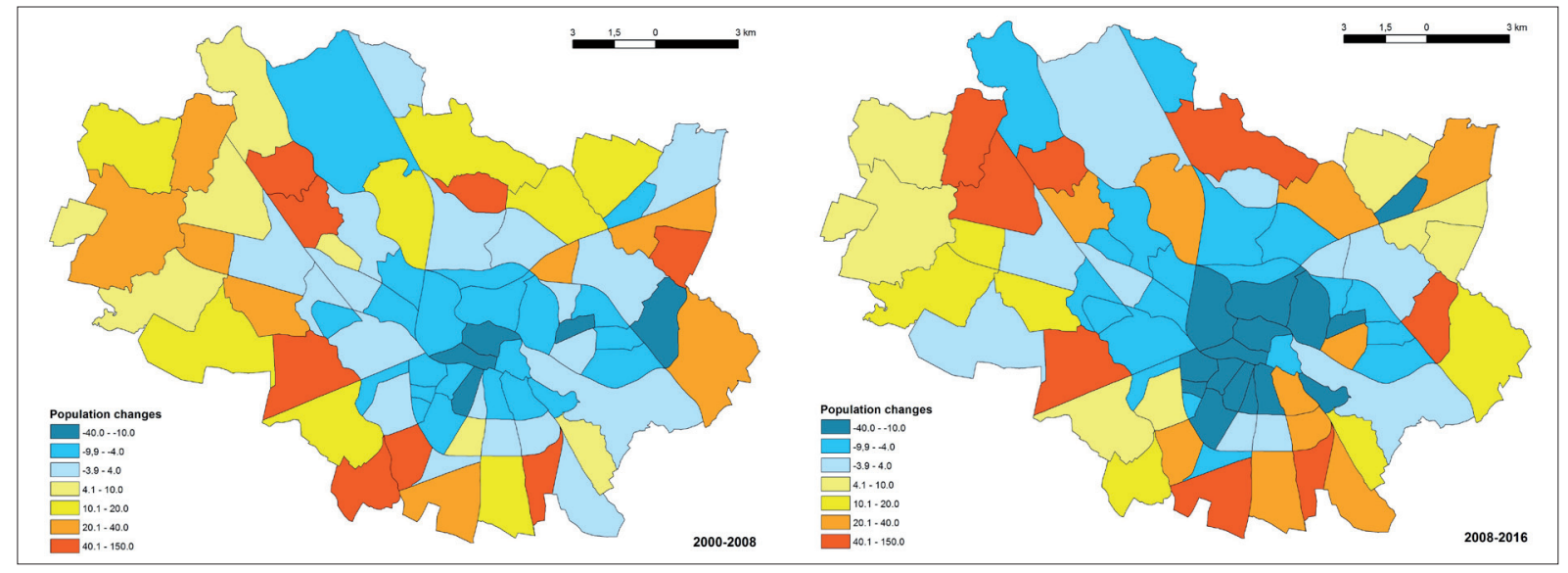

Fig. 7: Population changes in the city districts of Wroctaw (2000-2016)

Source: author's elaboration based on Wroctaw Spatial Information System data

years 2000-2016, city areas covering the peripheral districts of the city recorded a growth in population density of 125 persons per $\mathrm{km}^{2}(3.9 \%)$ : in the case of the Krzyki, of 86 persons per $\mathrm{km}^{2}(5.1 \%)$; in the case of the Fabryczna; and of 116 persons per $\mathrm{km}^{2}$ in the case of the Psie Pole. Meanwhile, in the central part of the city an outflow of residents is taking place (of $23.9 \%$ in the Stare Miasto and $17.1 \%$ in the Śródmieście), resulting in a fall in the number of permanent residents (but not necessarily a fall in population density in this area, which is a result of the difference between the actual number of residents and the number recorded in official statistics - this phenomenon is well illustrated by a comparison of data on the size of construction activity in the city and on population changes). With regard to changes in population structures, in peripheral districts the age structure is rejuvenated, and demographic ageing is noted in the central part of the city, which indicates that intra-urban migration is selective (Fig. 8).

Changes in morphology are connected to intensive construction activity occurring in peripheral districts of the city. In the years $2000-2016,82.7$ thousand of flats were commissioned within Wrocław city, $90.6 \%$ of which were in peripheral districts (Krzyki 32.6 thousand, Fabryczna 25.9 thousand, Psie Pole 16.3 thousand). Interestingly, the size of construction activity in Wrocław is far higher than in its suburban zone (construction activity in Wrocław amounted to $65.2 \%$ of the total number of dwellings completed in the Wrockaw agglomeration as a whole: see Fig. 9), and the intensity of construction activity in 2016 approached values observed in the first ring of communes surrounding the city (in individual zones of the agglomeration it was: 13.3 dwellings per 1,000 residents in the case of the city, 16.6 in the case of the first ring and 4.5 in the case of the second ring of communes).

Furthermore, the intensity of construction activity in the case of the peripheral districts of Wrocław is currently even higher than in the first ring of suburban zone communes (16.7 dwellings per 1,000 residents). Also noticeable is that in the case of the first ring of the suburban zone, intensive construction activity (over 7.0 dwellings per 1,000 inhabitants

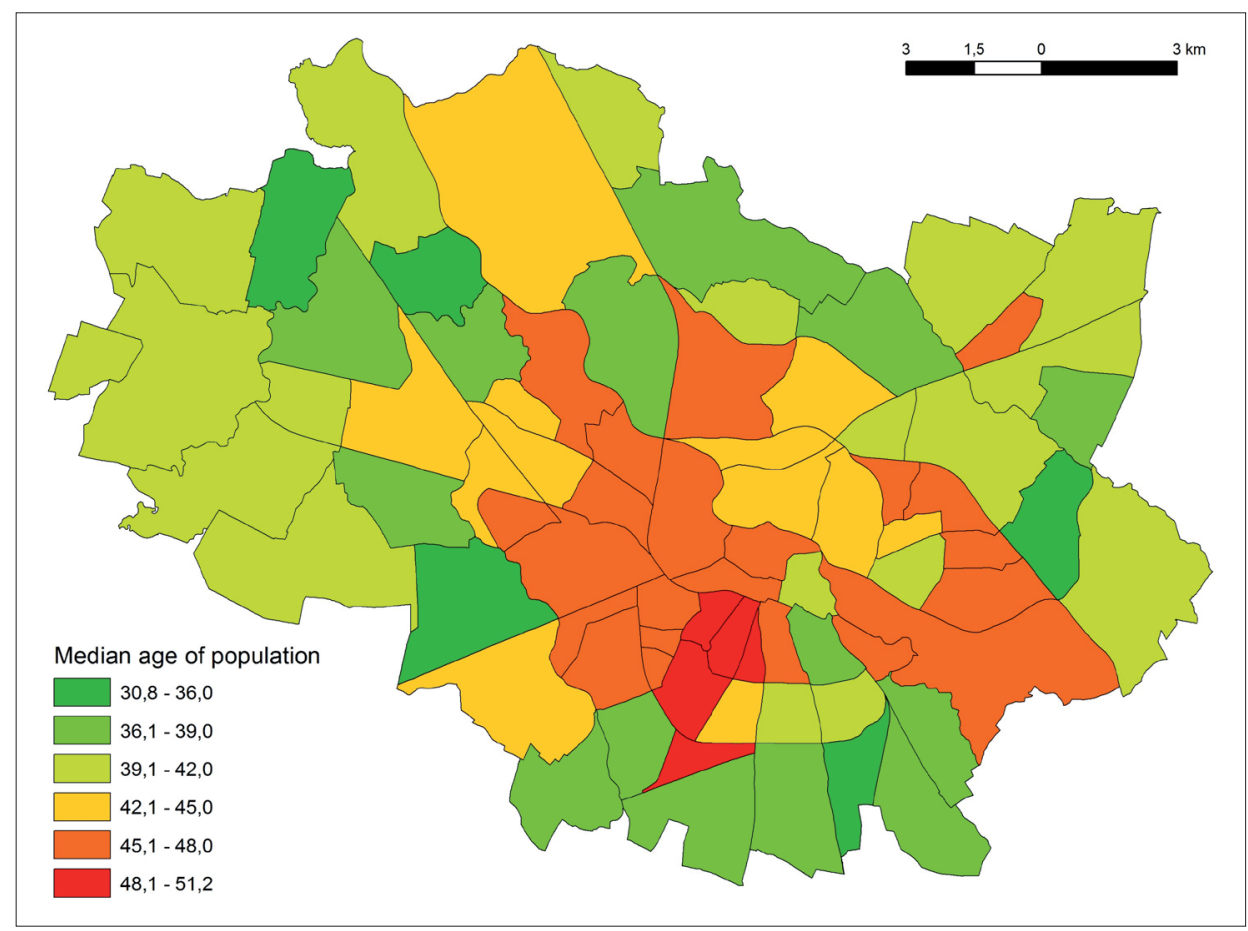

Fig. 8: Median age of population in city districts of Wroctaw (2016)

Source: author's elaboration based on Wroctaw Spatial Information System data 


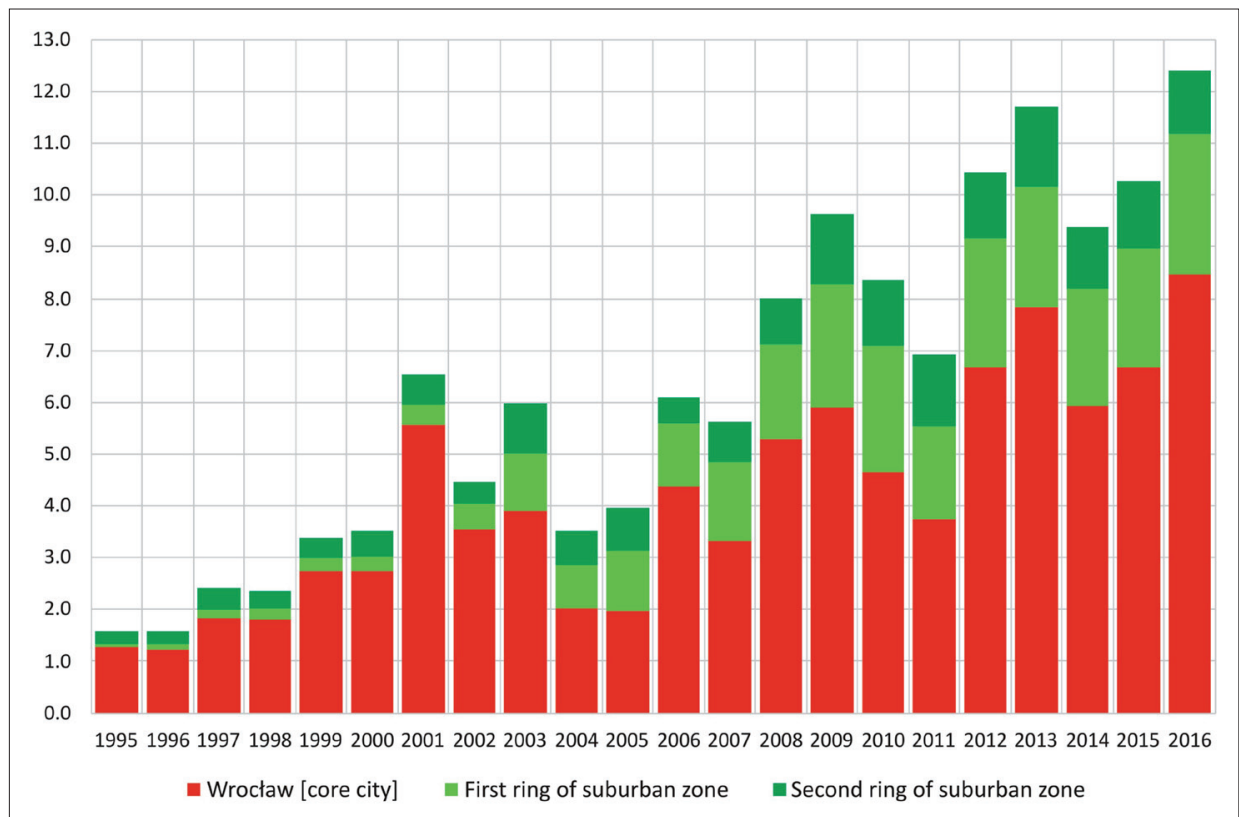

Fig. 9: Dwellings completed [in thousands] in Wroctaw and its suburban areas (1995-2016) Source: author's elaboration based on Local Data Bank (Statistics Poland)

annually) has been present since 2003, while in the case of the peripheral districts of the city, it is only since 2006 , which may be interpreted as a reaction of the city to suburbanisation processes that are unfavourable to it. The size of construction activity in Wrocław in the years 2000-2016 suggests a growth of the population of the city (the growth may be estimated as some 200 to 220 thousand inhabitants ${ }^{5}$ ), while according to official statistical data in this period the population of the city lost around 2.9 thousand inhabitants. This difference results mainly from the fact that the people coming to large cities in Poland rarely register a change in official place of residence (and in the official statistics, this is shown as the population inhabiting other settlements, and not as the population of the city of actual residence).

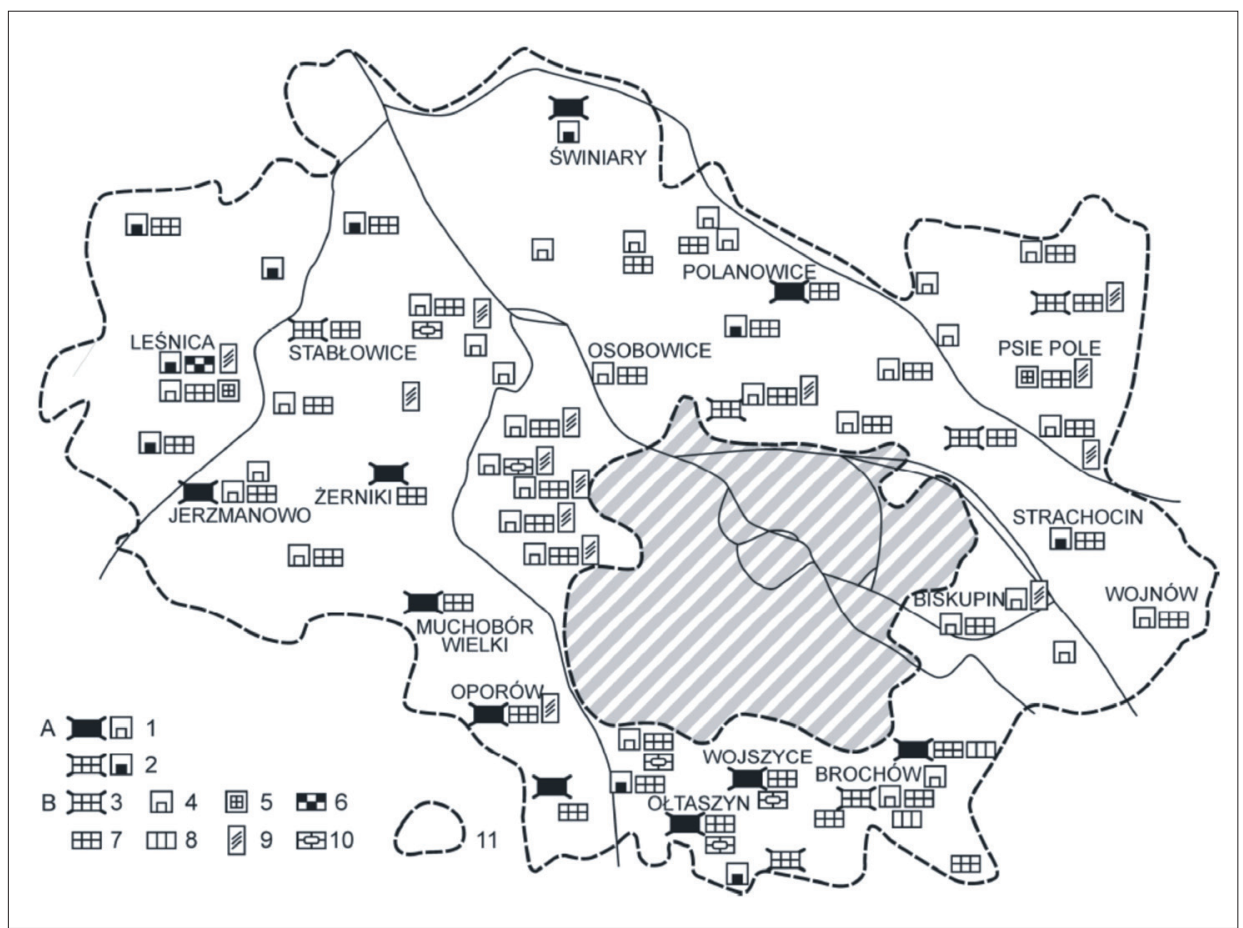

Fig. 10: Morphological transformations of the settlements incorporated into Wroctaw after 1928 according to Miszewska (1996). Source: author's elaboration

Legend: A) according to the morphological structure: 1 - villages with preserved original structures; 2 - villages with a blurred structure; B) according to morphological units: 3 - street-green village; 4 - grange; 5 - rent development in incorporated towns. Villa estates: 6 - from the beginning of the $20^{\text {th }}$ century, 7 - from the interwar period, $10-$ postwar. Multi-family housing: 8 - terraced, 9 - modern block of flats, 11 - city border until 1928

\footnotetext{
${ }^{5}$ This estimate is based on the product of number of commissioned flats and the average number of persons per flat (around 2.5-2.6).
} 
Construction activity in the peripheral districts of the city contributes to significant changes in their morphology and spatial structures. These districts grew from former villages that were incorporated into the Wrocław borders mainly as a result of the broadening of its territory in the $20^{\text {th }}$ century. In the inter-war period, villa estates, or estates with terraced housing usually meant for workers, were built in place or in the neighbourhood of former villages. In the years 1945-1989 in the areas of former villages, tower block estates or villa estates were built, and contemporarily (post1989) mainly villa or multi-family housing developments are being built there. The processes of spatial development in the peripheral zone of Wrocław city resulted in the transformation of its landscape (Miszewska, 1996) by:

1. Change in land use, which usually leads to agricultural land being pushed out from built-up areas;

2. Growth of the road network, which turned districts into morphological units with complex structures; and

3. Morphological units where initial (rural) forms are located alongside more advanced units with a (sub)urban character.
City districts of rural origin differ in the advancement of their morphological transformations, which is related to their location within city boundaries. Districts that are further away from the city centre and main transport routes were subject to far less intensive morphological transformation than districts located closer to the area of high-density developments (see Fig. 10 on previous page).

The contemporary construction activity in the peripheral parts of the city contributes to further morphological transformations in their spatial layout and physiognomy. New buildings or residential districts, consisting of detached (Fig. 11), semi-detached and terraced (Fig. 12) housing, are built mainly in areas previously used for agriculture ('greenfields'). The original rural or farm buildings are also being replaced by new multi-family buildings.

\subsection{Demographic features of intra-urban suburbs in Wrocław}

An analysis of the population structures in modern estates forming intra-urban suburbs in Wrocław shows certain patterns. Multi-family housing estates built by development companies are, irrespective of their size, inhabited mainly

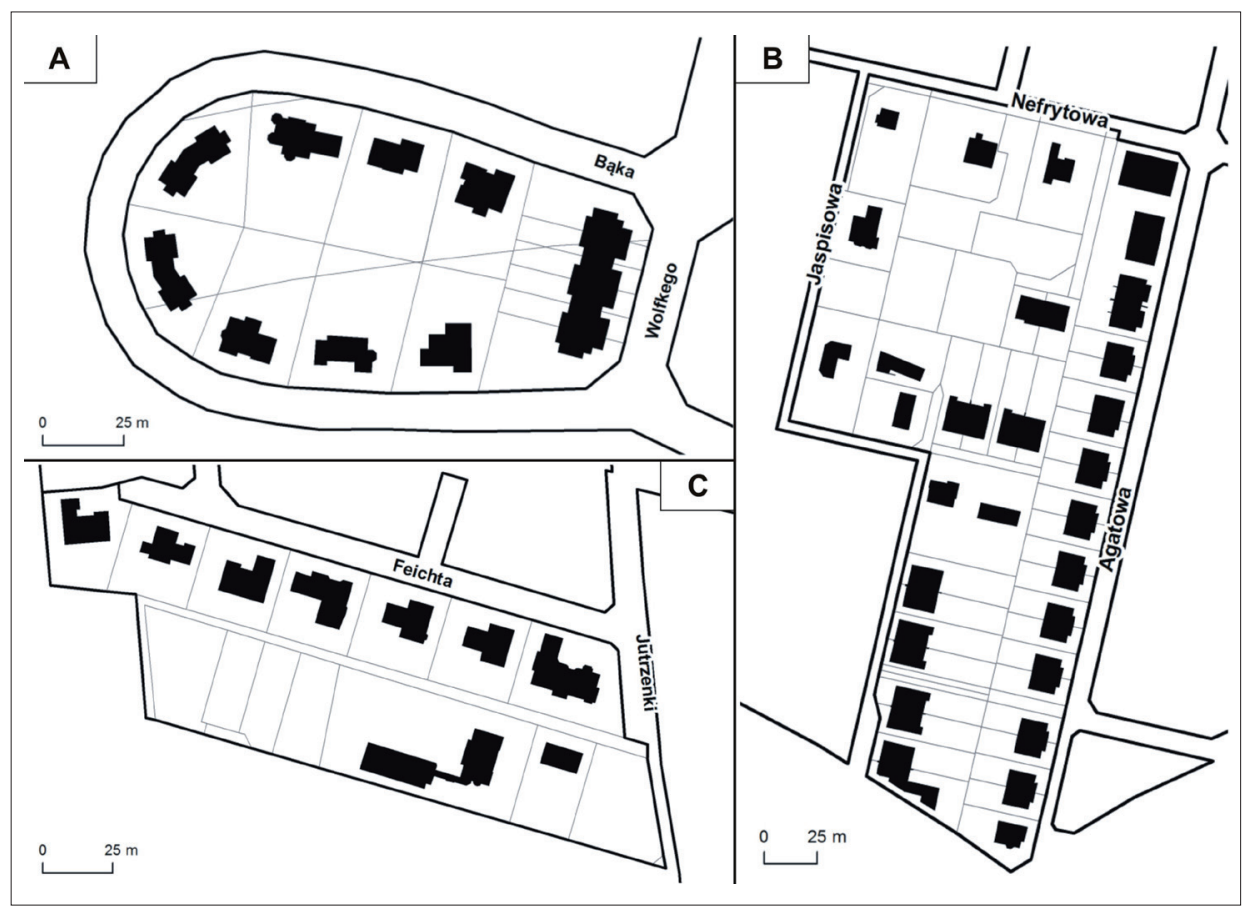

Fig. 11: Detached housing forming intra-urban suburbs in Wroctaw: A - Marszowice, B - Ottaszyn, C-Oporów Source: author's elaboration

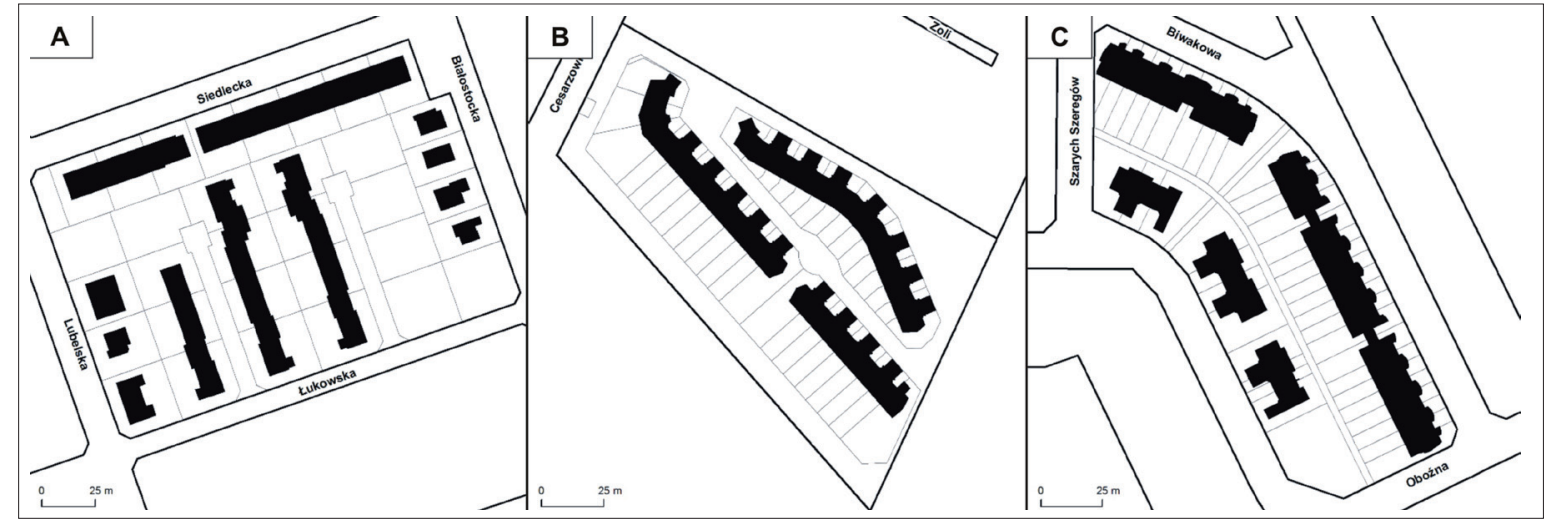

Fig. 12: Semi-detached housing forming intra-urban suburbs in Wroctaw: A - Maślice, B - Oporów, C-Wojszyce Source: author's elaboration 
by families with small children. In all the investigated housing estates or residential districts, the mobile working age population (25-45 years) and children under 14 years dominate (Fig. 13).

The median population age in 2016 was 26.5 years in the case of the estate at Żernicka Street, 28.3 years for the estate at Lipa Piotrowska and 28.8 years for the Jagodno estate (compared to the average for Polish cities of 41 years). In all cases, the proportion of the population of pre-working age was over 30\% (average for Polish cities: 15.7\%), while the share of population of post-working age was around 5-6\% (compared to the average for Polish cities of $22.3 \%$ ). Furthermore, as shown by the survey, at the estate at Żernicka Street the real number of estate inhabitants was significantly different from the population recorded in the official statistics (the data for this estate from the PESEL database underestimated the real population by around 34\%). A similar underestimation occurs in other housing estates analysed. This is evidenced by the number of "empty" apartments, for which there is no data on the population living there in the official PESEL database.

Meanwhile, a slightly different picture is offered by the population structure by sex and age in communal multifamily housing estates (the estate at Wojanowska Street), as well as the single-family housing estates built by development companies (the Malownicze estate). Here, the largest proportion is of the working age population (25-49 years) and children under 19 years (Fig. 14). There is also a far higher share of post-working age populations (in the case of the Malownicze estate it was $6.7 \%$, and for the estate at Wojanowska Street, 11.4\%).

The median age for the two estates was 29.5 (Malownicze estate) and 32.6 years (Wojanowska Street). On both estates, the population structure is similar to population structures of single-family residential districts in the first ring of suburban zone (Fig. 15)

This can be related to individual population groups having differing preferences with respect to place of residence within the agglomeration space. Single-family residential districts (located both within city borders and in the suburban zone) are settled mainly by 'well-off' residents with a stable situation (the so-called upper middle class, who can afford to buy their own house). New estates with multifamily housing, on the other hand, are settled by residents who are slightly less well-off, but who can still afford to buy their own flat (the so-called lower middle class). This may indicate the selective nature of suburbanisation. Multifamily housing estates are usually built in the peripheral

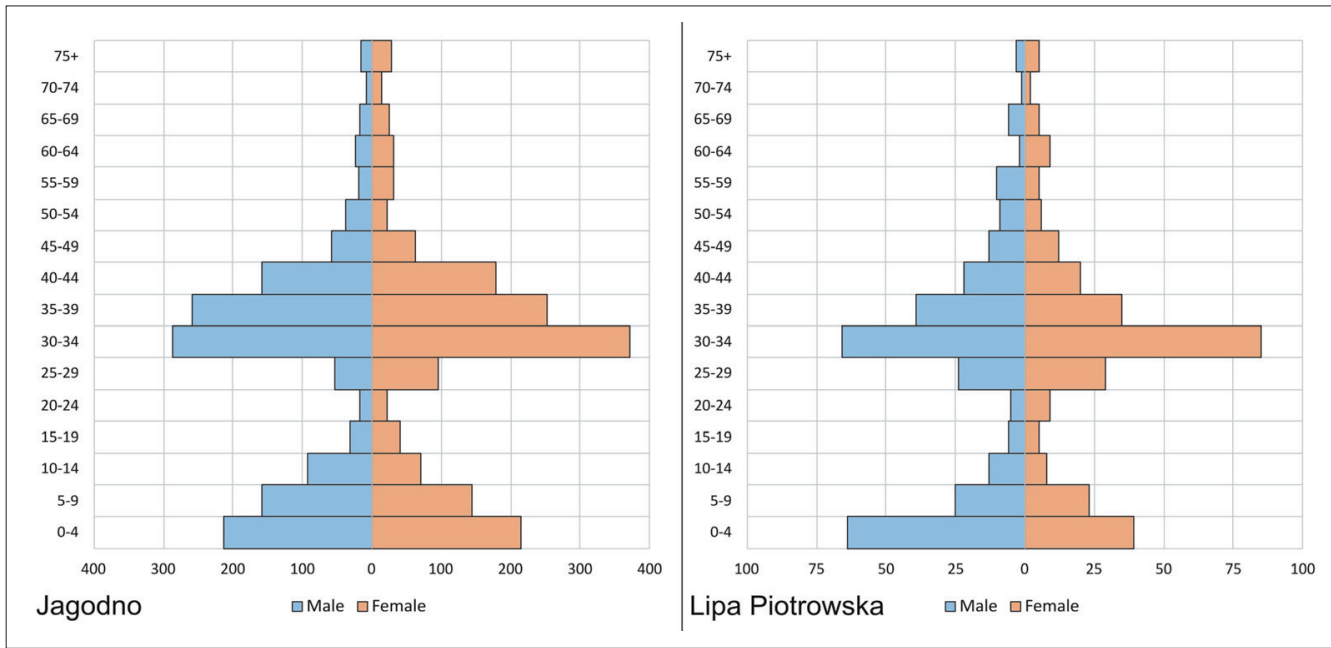

Fig. 13: Population by sex and age in multi-family housing estates built by development companies in Wroctaw (2016) Source: author's elaboration based on PESEL database

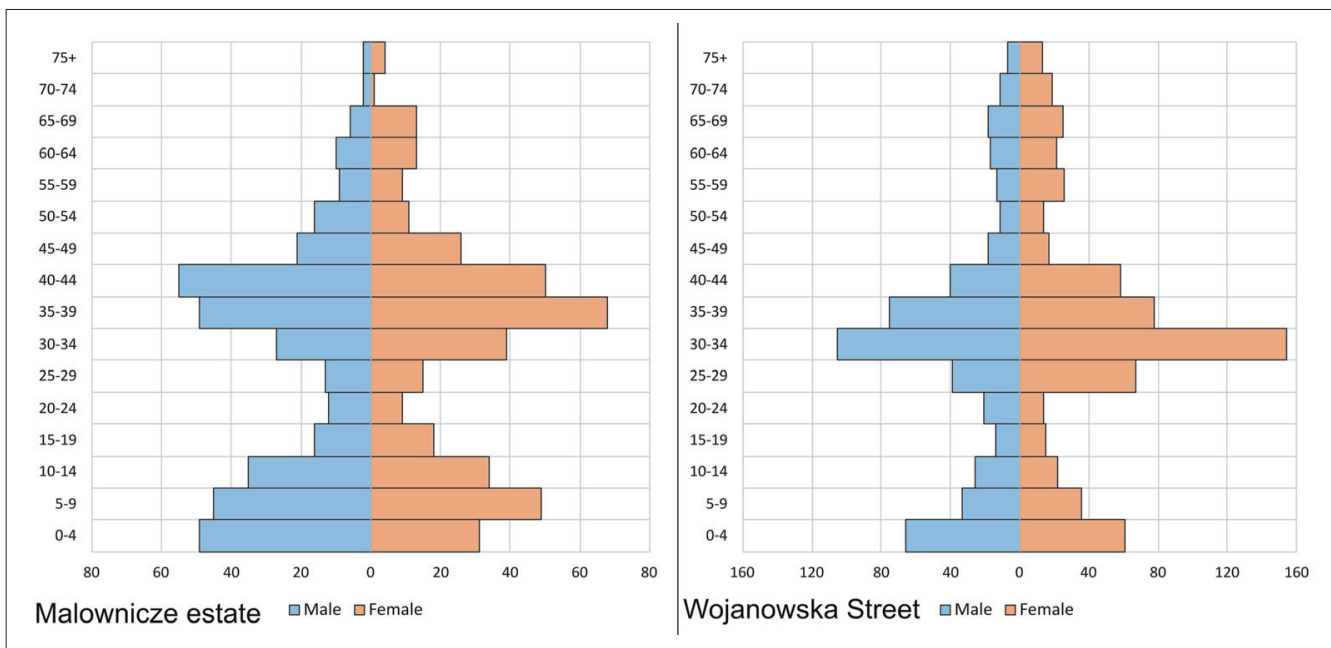

Fig. 14: Population by sex and age in single-family residential districts built by development companies and communal multi-family housing estates in Wroctaw (2016)

Source: author's elaboration based on PESEL database 


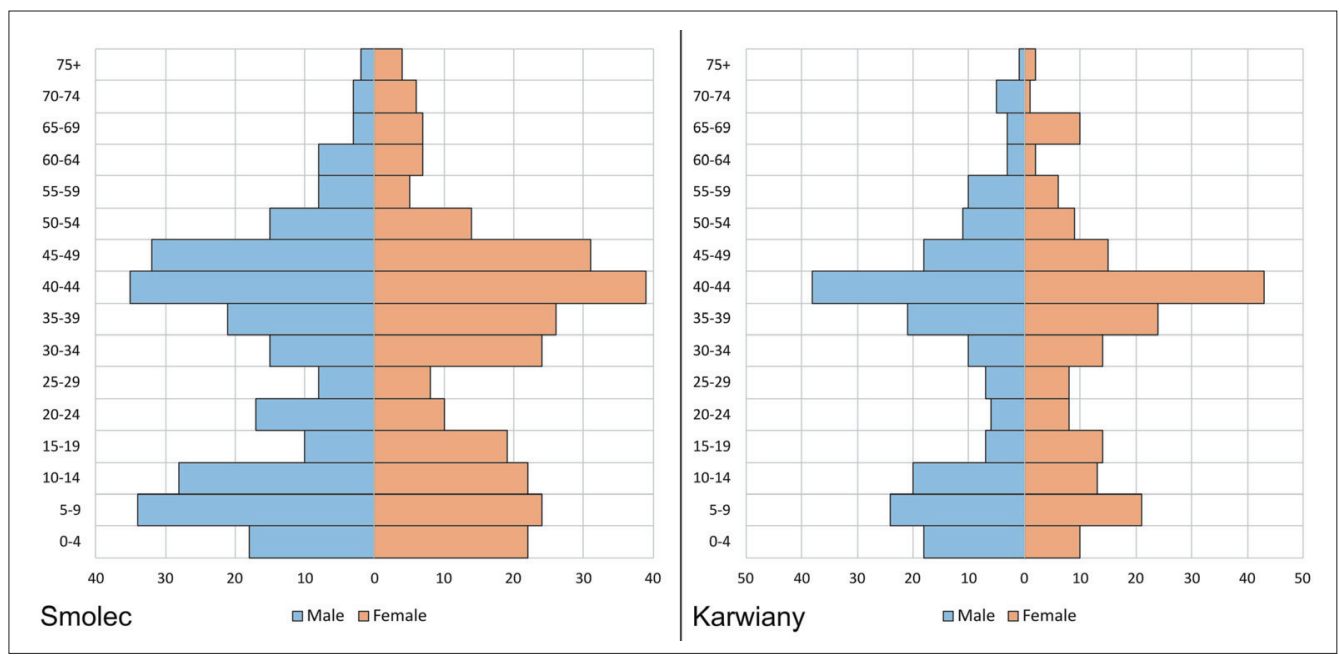

Fig. 15: Population by sex and age in single-family residential districts in the suburban zone of Wroctaw (2016) Source: author's elaboration based on PESEL database

zone of the city, but within the city borders (intra-urban suburbs), while villa estates are more often built in the proper (outer) suburban zone.

Despite the differences identified in various types of housing estates, the influx of people to the area of the intraurban suburbs contributes to a significant rejuvenation of their population structures. It stands in contradiction to the problem of the ageing of cities located in Central and Eastern Europe, which is widely described in the literature (e.g. Hoff, 2011; Kurek, 2011; Kabisch and Grossmann, 2013). This process undoubtedly occurs, but it concerns the most central parts of post-socialist cities, while their peripheral zones are characterised by a different demographic specificity. The different population structures are also related to the different needs of the people living in the analysed parts of the city, which may have specific consequences for urban governance.

The results of the survey conducted in 2018 in the Żernicka Street estate demonstrate that $75 \%$ of the resident adult population has higher education (they are mainly specialists, office workers, teachers and engineers), and small business owners dominate among the rest (22\%). Most persons on the estate (73\%) previously lived in Wrocław, mainly in the central districts of the city (in the Stare Miasto or Śródmieście), which indicates the direction of population movements within the city (from the centre to the peripheral zones) consistent with the essence of suburbanisation. Interestingly, more than half of this group of residents (52\%) indicated that they had not lived in Wrocław since birth, and their arrival in the city was associated with studies or taking up their first job. The remaining residents of the estate came to Wrocław mainly from medium-sized towns located up to $150 \mathrm{~km}$ away from the city. Among the residents of the housing estate, young married couples with children (51\%) and couples without children $(37 \%)$ predominate, and the average number of people per apartment is 2.57.

From this survey, the most important factors in choosing the current place of residence included: quiet, calm and attractive area $(63 \%)$; good location of the estate, mainly near the workplace (60\%); and attractive price - lower than in the city centre (54\%). Other factors included the character of the estate - a small gated-estate (32\%), and good accessibility in terms of transport - near the motorway ring road and close to the city centre $(20 \%)$. The most frequently indicated disadvantages of the current place of residence included: the vicinity of railway tracks and a busy street (43\%); the lack of services near the housing estate (34\%); and the lack of parking spaces (27\%). In the case of Katowice (see Twardzik and Halama, 2017), inhabitants of the southern districts (Podlesie, Kostuchna and Zarzecze) also indicated similar advantages of living on the peripheral districts of the city (quiet, calm, proximity of green areas, far from the centre, options for active leisure).

\subsection{Determinants of intra-urban suburbanisation in CEE cities}

Urban sprawl and chaotic development patterns are two of the main negative urban patterns of post-socialist urban transformations in Central and Eastern European cities. The costs of sprawl are also one of the main negative urban impacts on urban development (Hirt and Stanilov, 2009). This is because suburban sprawl is believed to have significantly contributed to increased vehicle use, land consumption and higher household energy consumption (Kahn, 2000). Increasing transportation between the hinterland and the core causes traffic jams on radial communications in the inner and outer city (Ouředníček, 2007; Sýkora and Ouředníček, 2007). In Poland, the losses that households are facing due to chaotic suburbanisation can be assessed as high. These losses concern all residents of suburbs because intensification of the process of chaotic suburbanisation has financial consequences not only for the migrants but also for native villagers (by extending the time of travel and related costs). In order to reduce the negative economic consequences, it is necessary to design and implement a coherent road infrastructure solution for the city and surrounding municipalities (Lityński and Hołuj, 2017).

Another way of minimising costs of living in new developments is looking for free space for investment within city limits. This is particularly important for urban authorities. Suburbanisation contributes not only to increasing road traffic or the necessity of serving populations de facto from outside the city: for the city and its budget, loss of population also means loss of tax revenue. Thus, urban authorities are themselves interested in keeping inhabitants within city borders. In the case of the larger cities of Central and Eastern Europe, the presence of large non-urbanised areas, particularly agricultural land, which can now serve as potential space for new construction investments, results from the features of territorial development of the cities 
during the socialist period (Szmytkie and Krzysztofik, 2019). Such incorporation processes contributed to a significant expansion of city limits - for the largest cities in Poland (Szymańska et al., 2009; Szmytkie and Krzysztofik, 2019), for Prague (Sýkora, 1999; Sýkora and Ouředníček, 2007), for Bratislava (Feráková and Jarolímek, 2011), for Belgrade and Sofia (Slaev et al., 2018) or for Budapest (Soós and Ignits, 2003; Egedy et al., 2017). Further, Spórna and Krzysztofik (2020) have identified primary factors of 'inner' suburbanisation development in the Katowice conurbation, which are: (1) polycentrism of the settlement form imposed by the development of a group of mining and industrial cities and estates; (2) the existence of large agricultural areas between compact zones of residential, industrial and service developments; (3) a mosaic pattern of spatial and functional structures in the Katowice conurbation core; (4) changes in the family model, social changes; (5) changes in the macroeconomic dimension, growing prosperity of the population; (6) the development of the speculative real estate market; (7) EU entry; (8) 'Flexibly applicable' of the Planning and Spatial Development Act and the Building Law Act; (9) the mosaic of forest areas, cultivated green areas and reservoirs; (10) a dense road network, including national roads and motorways; and (11) an insufficient number and area of flats, despite strong socialist urbanisation. These factors seem to be considered as generally applicable in the development of intra-urban suburbanisation in Central and Eastern European cities.

Studies carried out in recent years have shown that areas of new residential developments within the boundaries of large cities in Central and Eastern Europe are characterised by good transport accessibility, competitive prices of land compared to rural areas, and access to green areas. As such, they constitute convenient migration destinations for urban populations (Katowice conurbation - Spórna, 2018); they emerge in areas with good environmental conditions (Bratislava - Ira, 2003); they have been the exclusive targets of dominant migration flows where housing supply has had considerable time-space consequences for the spatial pattern of population growth through migration (Prague - Sýkora and Čermák, 1998); and they are populated by affluent individuals as reflected by the spatial distribution of mansions (Łódź - Szafrańska et al., 2019). In Warsaw, after 2000 the scale of housing supply built by developers began to increase dynamically. Centrally located projects were typically infill developments in the existing urban fabric that are often, though to a varying extent, adjusted to the adjacent urban fabric. In contrast, sub-central and peripheral investments were often large-scale housing estates that consume a greater amount of land, often including an internal road infrastructure on a private estate that locks out outsiders and has no connection to its immediate surroundings (Stepniak and Mendel, 2013). In the Katowice conurbation, intra-urban suburbanisation occurs primarily on postagricultural land, and to a lesser extent on brownfield sites. In the conurbation as a whole, the development of mid-sized and small clusters is predominant. The largest clusters of new residential developments include areas located in the built-up area and its immediate surroundings (up to $1 \mathrm{~km}$ away) (Spórna and Krzysztofik, 2020).

\section{Discussion}

Wrocław is an example of a city that is undergoing intensive suburbanisation processes. These processes started in the 1990s along with the socio-economic transformation and intensified in the 2000s. Moreover, in this case suburbanisation is manifested not only in the development of individual residential construction in the suburban zone (so-called residential suburbanisation), but also has the nature of commercial suburbanisation, with the effect of business activity development in the near suburban zone (Brezdeń and Szmytkie, 2019). Processes occurring in the surroundings of Wrocław are thus like those observed in the surroundings of other large cities in Central and Eastern Europe (compare: Sýkora, 1999; Lowe and Tsenkova, 2003; Soós and Ignits, 2003; Hamilton et al., 2005; Nuissl and Rink, 2005; Hirt and Stanilov, 2007; Sýkora and Ouředníček, 2007; Brade et al., 2009; Kubeš, 2013; Martyniuk et al., 2016). Intensive suburbanisation, which is characteristic for post-socialist countries, supported in Poland by the liberal planning law and a still strong societal desire to live outside the city, have led to the development of new settlement units and separated clusters of buildings (Mantey and Sudra, 2018).

In contrast, the development of peripheral districts located within city limits has a similarly intensive character. Suburbanisation in the classical sense (Berg et al., 1982) involves demographic development of the suburban zone with a simultaneous decline of population (depopulation) in the agglomeration core (central city). In the case of Wrocław the situation is slightly more complex. The central part of the city (Stare Miasto, Śródmieście) is indeed undergoing depopulation. The decline in population is also ongoing in large panel block estates from the socialist period, which is typical for post-socialist cities (e.g. Soós and Ignits, 2003; Banzhaf et al., 2007; Steinführer and Haase, 2007; Sýkora and Ouředníček, 2007; Brade et al., 2009; Marcińczak, 2012; Stępniak and Mendel, 2013; Haase and Rink, 2015; Spórna, 2018; Szafrańska et al., 2019). In former villages incorporated into city boundaries in the $20^{\text {th }}$ century, however, the population situation is different. Due to a large surface of agricultural land within their areas, researchers note the high construction activity which contributes to a growth in number of inhabitants. The character and intensity of these processes is reminiscent of suburbanisation processes occurring in the first ring of the suburban zone. Due to their location with respect to the agglomeration core, they can be called intra-urban suburbanisation (see Koman, 2017; Spórna, 2018; Szafrańska et al., 2019, Spórna and Krzysztofik, 2020). Importantly, the scale and dynamics of this process are comparable to those observed in the surroundings of the city, and the intensity of construction traffic inside the city may be even greater than in the suburban area. The importance of intra-urban suburbanisation is also manifested in the increase in population and the rejuvenation of the population structures of the peripheral parts of the city (in opposition to depopulating and ageing central areas), which shapes the duality of the demographic situation within the city. Broadly speaking, this process can be interpreted as the reaction of the city to the suburbanisation processes, which are unfavourable to the city (Kahn, 2000; Hirt and Stanilov, 2009; Lityński and Hołuj, 2017).

Due to the administrative distinctiveness of the suburban communes, the city cannot directly influence the activities undertaken in its vicinity. With free land for development, however, it can create opportunities for construction within the city. One factor that made the start of intra-urban suburbanisation processes possible in Wrocław was the significant expansion of city borders in the $20^{\text {th }}$ century. Incorporation processes were one of the most important 
factors of development of large cities in Poland (Szymańska et al., 2009; Szmytkie and Krzysztofik, 2019) and in other Central and Eastern European countries (Sýkora, 1999; Soós and Ignits, 2003; Sýkora and Ouředníček, 2007; Swianiewicz, 2010), while they are rarely found in Western European countries. The territorial expansion of cities often exceeded the capabilities of their real (rural) spatial development, and thus weakly urbanised peripheral city districts preserved their original character, simultaneously keeping a significant area of undeveloped and non-urbanised land (today potentially investment land). The problem with non-urbanised spaces within the city borders also concerned cities that developed polycentrically, e.g. cities of the Katowice conurbation (Spórna, 2018) or so-called city conglomerates (Szmytkie and Krzysztofik, 2019). This may explain the formation of intra-urban suburbs in central (in the geometrical sense) parts of cities in the Katowice conurbation (see Koman, 2017; Spórna, 2018, Spórna and Krzysztofik, 2020).

New construction projects in Poland are also often located in the area of urban gardens, which play a significant role in urban space as green environments, as new sociations, and even locations of food production. The character of the territorial development of large post-socialist cities in CEE and the specific nature of modern intra-urban population changes prompt a further investigation into the spatial structure of urban agglomerations in the region. In the case of Wrocław, the core of the urban agglomeration actually covers a densely built-up area whose boundaries approximately cover the territory of the city from the start of the $20^{\text {th }}$ century and an area of high-rise blocks from the socialist period. Around the agglomeration core, there is a ring of intra-urban suburbs which cover the area of former villages incorporated into the city in the $20^{\text {th }}$ century. This ring turns into the first ring of the real suburban zone, as in their area residential suburbanisation sometimes occurs even independently of administrative borders. A good example of this is the spatial development of the districts of Ołtaszyn and Partynice in Wrocław on the territory of Wysoka village (Kobierzyce commune). The outer zone of the agglomeration is formed by the second ring of communes surrounding the city (see Brezdeń and Szmytkie, 2019). According to Spórna and Krzysztofik (2020), intra-urban suburbanisation may also be an interesting tool for channelling spatial development towards the centre of a settlement system. This phenomenon may counteract the processes of urban decentralisation, although maintaining urban sustainability during this process is important (Jabareen, 2006; Talen, 2014). This interpretation of the process is a reference to the 'compact cities' concept (Dieleman and Wegener, 2004), and may be of especial interest for cities and urban agglomerations with a distributed or chaotic layout.

\section{Conclusion}

The intra-urban suburbanisation phenomenon is characterised by intensive construction activity and population growth in peripheral districts of the city. Such processes are counter to depopulation processes observed in central parts of the city and in the large panel block estates (i.e. in the agglomeration core). This duality of demographic changes within city borders contributes to significant changes in the distribution and structure of the population in the relationship between the centre and peripheral districts of the city, and also to the significant changes within city space, particularly in morphology. As regards changes in population structures, the population structure by age is rejuvenated in peripheral districts, while demographic ageing is noted in central parts of the city. Construction activity in central districts leads to infill developments in the existing urban fabric. In contrast, sub-central and peripheral investments are often large-scale residential districts that consume a greater amount of land, lock out outsiders and have no connection to their immediate surroundings. The size of construction activity in Wrocław suggests that the population of the city is growing (the increase may be estimated at even 200 to 220 thousand persons since 2000), while according to official statistical data in this period the number of inhabitants of the city decreased by approximately 2.9 thousand persons.

The population in the suburban zones of large cities is similarly underestimated. This difference suggests that official statistical data require verification with respect to changes in population numbers in large cities of Poland and their surroundings. Intra-urban suburbanisation, in terms of scale, dynamics and character, is like classic suburbanisation, understood as the development of suburbs, but occurs within the administrative boundaries of the city. Hence, it is omitted from official statistics that are averaged for the city as a whole, helping to mitigate depopulation and other negative processes occurring in the central parts of cities. At the same time, the dualism of socio-economic processes (and the resulting needs of residents) within the city is a challenge for planning and urban governance (see Spórna and Krzysztofik, 2020). In this context, research aimed at identifying internal suburbanisation and the characteristics of the process appear to be important. It is also worth considering the issue what kind of suburban development is more sustainable and useful for the city, and how can the city use planning and policy for management of such developments. This question implies the need for further research on the problem of intra-urban suburbanisation.

\section{References:}

BAGIŃSKA, J., SZMYTKIE, R. (2005): Population changes in large Polish cities in the end of $20^{\text {th }}$ century. Bulletin of Geography. Socio-economic Series, 4: 5-13.

BANZHAF, E., KINDLER, A., HAASE, D. (2007): Monitoring, mapping and modelling urban decline: A multi-scale approach for Leipzig, Germany. EARSeL eProceedings, 6(2): 101-114.

BAUM-SNOW, N. (2007). Did highways cause suburbanization? The Quarterly Journal of Economics, 122(2): 775-805.

VAN DEN BERG, L., DREWETT, R., KLAASEN, L. H., ROSSI, A., VIJVERBERG, C. H. (1982): Urban Europe: A study of growth and decline. Oxford, Pergamon Press.

BEAUREGARD, R.A. (2006): When America became suburban. Minneapolis, University of Minnesota Press.

BRADE, I., SMIGIEL, C., KOVÁCS, Z. (2009): Suburban residential development in post-socialist urban regions: The case of Moscow, Sofia, and Budapest. In: Kilper, H. [ed.]: German Annual of Spatial Research and Policy 2009: New Disparities in Spatial Development in Europe (pp. 79-104). Berlin - Heidelberg, Springer.

BREZDEŃ, P., SZMYTKIE, R. (2019): Changes in the Location of Industry in the Suburban Zone of a PostSocialist City. Case Study of Wrocław (Poland). Tijdschrift voor Economische en Sociale Geografie, 110(2): 102-122. 
BRUEGMANN, R. (2006): Sprawl: A Compact History. Chicago, University of Chicago Press.

CAVES, R. W. [ed.] (2005): Encyclopedia of the City. London, New York, Taylor and Francis.

CHAMPION, T. (2001): Urbanization, suburbanization, counterurbanization and reurbanization. In: Paddison, $R$ [ed.]: Handbook of urban studies (pp. 143-161). London, Thousand Oaks, New Delhi, Sage Publications.

CIOK, S. (2017): Budownictwo mieszkaniowe w strefie podmiejskiej Wrocławia. Space-Society-Economy, 13: $127-147$.

DAWSON, A. (1987): Planning in Eastern Europe. London, Croom Helm.

DIELEMAN, F., WEGENER, M. (2004): Compact city and urban sprawl. Built Environment, 30(4): 308-323.

EGEDY, T., KOVÁCS, Z., KONDOR, A. C. (2017): Metropolitan region building and territorial development in Budapest: The role of national policies. International Planning Studies, 22(1): 14-29.

FERÁKOVÁ, V., JAROLÍMEK, I. (2011): Bratislava. In: Kelcey, J. G., Müller, N. [eds.]: Plants and habitats of European cities (pp. 79-129). Springer, New York, NY.

FORSYTH, A. (2012): Defining suburbs. Journal of Planning Literature, 27(3): 270-281.

FREY, H. W., FERGUSON, N. S., BAGAEEN, S. G., WOODS, L. (2006): Suburbs reconsidered: Form, mobility and sustainability. Built Environment, 32(3): 250-266.

GAŁKA, J., WARYCH-JURAS, A. (2018): Suburbanization and migration in Polish metropolitan areas during political transition. Acta Geographica Slovenica, 58(2): 63-72.

GARCIA-LÓPEZ, M.-Á., HOLL, A., VILADECANSMARSAL, E. (2015): Suburbanization and highways in Spain when the Romans and the Bourbons still shape its cities. Journal of Urban Economics, 85: 52-67.

HAASE, A., RINK, D. (2015): Inner-city transformation between reurbanization and gentrification: Leipzig, Eastern Germany. Geografie, 120(2): 226-250.

HAMILTON， F. E. I., DIMITROWSKA-ANDREWS， K., PICHLER-MILANOVIĆ, N. [eds.] (2005): Transformation of cities in Central and Eastern Europe - towards globalization. Tokyo, United Nations University Press.

HARRIS, R. (2010): Meaningful types in a world of suburbs. In: Clapson, M., Hutchinson, R. [eds.]: Suburbanization in global society (pp. 15-47). Bingley, Emerald.

HIRT, S., STANILOV, K. (2007): The perils of post-socialist transformation: Residential development in Sofia. In: Stanilov, K. [ed.]: The Post-Socialist City (pp. 215-244). Springer, Dordrecht.

HIRT, S., STANILOV, K. (2009): Twenty years of transition: The evolution of urban planning in Eastern Europe and the former Soviet Union, 1989-2009. Nairobi, Human Settlements Global Dialogue Series, UN Habitat.

HOFF, A. [ed.] (2011): Population ageing in Central and Eastern Europe: Societal and policy implications. Ashgate Publishing, Ltd.

HOLM, A., MARCIŃCZAK, S., OGRODOWCZYK, A. (2015): New-build gentrification in the post-socialist city: Łodź and Leipzig two decades after socialism. Geografie, 120(2): 164-187.
IRA, V. (2003): The changing intra-urban structure of the Bratislava city and its perception. Geografický časopis, 55: $91-108$.

JABAREEN, Y. R. (2006): Sustainable urban forms: Their typologies, models, and concepts. Journal of Planning Education and Research, 26(1): 38-52.

JINDRICH, J. (2012). Suburbs in the city. Reassessing the location of nineteenth-century American working-class suburbs. Social Science History, 36(2): 147-167.

KABISCH, S., GROSSMANN, K. (2013): Challenges for large housing estates in light of population decline and ageing: Results of a long-term survey in East Germany. Habitat International, 39: 232-239.

KAHN, M.E. (2000): The environmental impact of suburbanization. Journal of Policy Analysis and Management, 19(4): 569-586.

KNOX, P. L., McCARTHY, L. (2005): Urbanization: an introduction to urban geography. Upper Saddle River, NJ: Pearson Prentice Hall.

KOMAN, W. (2017): Suburbanizacja wewnętrzna Zabrza. Studia Miejskie, 26: 151-64.

KONTULY, T., GEYER, H. S. (2003): Lessons learned from testing the differential urbanization model. Tijdschrift voor Economische en Sociale Geografie, 94(1): 124-128.

KOTUS, J. (2006): Changes in the spatial structure of a large Polish city - The case of Poznań. Cities, 23(5): 364-381.

KOVÁCS, Z., FARKAS, Z. J., EGEDY, T., KONDOR, A. C., SZABÓ, B., LENNERT, J., KOHÁN, B. (2019): Urban sprawl and land conversion in post-socialist cities: The case of metropolitan Budapest. Cities, 92: 71-81.

KSIĄŻEK, S., SUSZCZEWICZ, M. (2017): City profile: Wrocław. Cities, 65: 51-65.

KUBEŠ, J. (2013): European post-socialist cities and their near hinterland in intra-urban geography literature. Bulletin of Geography. Socio-economic Series, 19: 19-43.

KULU, H. (2003): Housing differences in the late Soviet city: the case of Tartu, Estonia. International Journal of Urban and Regional Research, 27(4): 897-911.

KUREK, S. (2011): Double transitions? Regional patterns of population ageing in Poland. Geografiska Annaler: Series B, Human Geography, 93(2): 163-184.

LECHMAN, G. (2005): Problem suburbanizacji a kondycja istniejącej zabudowy miejskiej. In: Lorens, P. [ed.]: Problem suburbanizacji (pp. 33-44). Warszawa, Urbanista.

LEETMAA, K., TAMMARU, T., ANNISTE, K. (2009): From priority-led to market-led suburbanization in a postcommunist metropolis. Tijdschrift voor economische en sociale geografie. 100(4) 436-453.

LITYŃSKI, P., HOŁUJ, A. (2017): Urban sprawl costs: The valuation of households' losses in Poland. Journal of Settlements and Spatial Planning, 8(1): 11-35.

LOGAN, S. (2019): Learning from the Socialist Suburb. In: Güney, M., Keil, R., Üçoğlu, M. [eds.]: Massive Suburbanization: (Re)Building the Global Periphery. Toronto, University of Toronto Press.

LOWE, S., TSENKOVA, S. (2003): Housing Change in Central and Eastern Europe. Aldershot, Ashgate Publishing Ltd. 
MACE, A. (2009). Suburbanization. In: Kitchin, R., Thrift, N. [eds.]: International encyclopedia of human geography (pp. 77-81). Amsterdam, Oxford, Elsevier.

MARCIŃCZAK, S. (2012): The evolution of spatial patterns of residential segregation in Central European Cities: The Łódź Functional Urban Region from mature socialism to mature post-socialism. Cities, 29(5): 300-309.

MARTYNIUK, O., MARTYNIUK-PĘCZEK, J., PĘCZEK, G. (2016): Economic vitality of Polish suburbs. GSTF Journal of Engineering Technology (JET), 3(4): 39-48.

MATLOVIČ, R., SEDLÁKOVÁ, A. (2007): The Impact of Suburbanization in the Hinterland of Prešov. Moravian Geographical Reports, 15(2): 22-31.

MISZEWSKA, B. (1996): Struktura morfologiczna peryferyjnych osiedli. Prace Instytutu Geograficznego. Seria B: Geografia Społeczna i Ekonomiczna, 14: 53-61.

MUSIL, J. (1993): Changing urban systems in postcommunist societies in Central Europe: analysis and prediction. Urban Studies, 30(6): 899-905.

NAMYŚLAK, B., SIKORSKI, D. (2010): Charakterystyka zasobów mieszkaniowych aglomeracji wrocławskiej. Przegląd Geograficzny, 82(2): 241-255.

NUISSL, H., RINK, D. (2005): The 'production' of urban sprawl in eastern Germany as a phenomenon of postsocialist transformation. Cities, 22(2): 123-134.

OUŘEDNÍČEK, M. (2007): Differential suburban development in the Prague urban region. Geografiska Annaler: Series B, Human Geography, 89(2): 111-126.

PACIONE, M. (2001): Urban Geography: A Global Perspective. New York, Routledge.

RYKIEL, Z. (1984): Intra-metropolitan migration in the Warsaw agglomeration. Economic Geography, 60(1): 55-70.

SCHMIDT, S., FINA, S., SIEDENTOP, S. (2015): Postsocialist sprawl: A cross-country comparison. European Planning Studies, 23(7): 1357-1380.

SCHNEIDER-SLIWA, R. (2006): Global and local forces in cities undergoing political change. In: SchneiderSliwa, R. [ed.]: Cities in Transition. Globalization, Political Change and Urban Development (pp. 1-8). Dordrecht, Springer.

SAILER-FLIEGE, U. (1999): Characteristics of postsocialist urban transformation in East Central Europe. GeoJournal, 49(1): 7-16.

SLAEV, A. D., NEDOVIĆ-BUDIĆ, Z., KRUNIĆ, N., PETRIĆ, J., DASKALOVA, D. (2018): Suburbanization and sprawl in post-socialist Belgrade and Sofia. European Planning Studies, 26(7): 1389-1412.

SOÓS, G., IGNITS, G. (2003): Suburbanization and its consequences in the Budapest metropolitan area. Third EuroConference the European City in Transition, the City and the Region, Bauhaus-Universität Weimar, Germany, Supported by the European Commission.

SPÓRNA, T. (2018): The suburbanization process in a depopulation context in the Katowice conurbation, Poland. Environmental and Socio-economic Studies, 6(1): 57-72.

SPÓRNA, T., KRZYSZTOFIK, R. (2020): 'Inner' suburbanization. Background of the phenomenon in a polycentric, post-socialist and post-industrial region. Example from the Katowice conurbation, Poland. Cities, 104: 102789.

STANILOV, K. [ed.] (2007): The Post-Socialist City. Springer, Dordrecht.

STANILOV, K., SÝKORA, L. (2012): Planning, markets, and patterns of residential growth in metropolitan Prague. Journal of Architectural and Planning Research, 29(4): 278-291.

STEINFÜHRER, A., HAASE, A. (2007): Demographic change as a future challenge for cities in East Central Europe. Geografiska Annaler: Series B, Human Geography, 89(2): 183-195.

STĘPNIAK, M., MENDEL, M. (2013): New housing investments completed in Warsaw, 2002-2012. Geographia Polonica, 86(3): 281-286.

SWIANIEWICZ, P. (2010): If territorial fragmentation is a problem, is amalgamation a solution? An East European perspective. Local Government Studies, 36(2): 183-203.

SÝKORA, L. (1999) Changes in the internal spatial structure of post-communist Prague. GeoJournal 49(1): 79-89.

SÝKORA, L. (2001): Proměny prostorové struktury Prahy $\mathrm{v}$ kontextu postkomunistické transformace. In: Hampl, M. [ed.]: Regionální vývoj: specifika české transformace, evropská integrace a obecná teorie (pp. 127-166). Praha, DemoArt.

SÝKORA, L., BOUZAROVSKI, S. (2012): Multiple transformations: conceptualising the post-communist urban transition. Urban Studies 49(1): 43-60.

SÝKORA, L., ČERMÁK, Z. (1998): City growth and migration patterns in the context of 'communist' and 'transitory' periods in Prague's urban development. Espace - Populations - Sociétés, 16(3): 405-416.

SÝKORA, L., OUŘEDNÍČEK, M. (2007): Sprawling postcommunist metropolis: Commercial and residential suburbanization in Prague, Brno, the Czech Republic. In: Razin, E. et al. [eds.]: Employment Deconcentration in European Metropolitan Areas (pp. 209-233). Dordrecht, Springer.

SZAFRAŃSKA, E., DE LILLE, L. C., KAZIMIERCZAK, J. (2019): Urban shrinkage and housing in a post-socialist city: relationship between the demographic evolution and housing development in Łódź, Poland. Journal of Housing and the Built Environment, 34(2): 441-464.

SZMYTKIE, R. (2019): The Cyclical Nature of the Territorial Development of Large Cities: A Case Study of Wrocław (Poland). Journal of Urban History 0096144219877866.

SZMYTKIE, R., KRZYSZTOFIK, R. (2019): The processes of incorporation and secession of urban and suburban municipalities: The case of Poland. Norsk Geografisk Tidsskrift - Norwegian Journal of Geography, 73(2): 110-127.

SZYMAŃSKA, D., GRZELAK-KOSTULSKA, E., HOŁOWIECKA, B. (2009): Polish towns and the changes in their areas and population densities. Bulletin of Geography. Socio-economic Series, 11: 15-29.

ŚLESZYŃSKI, P. (2005): Perspektywy rozwoju rynku mieszkaniowego w Polsce w świetle sytuacji demograficznej, ekonomicznej i stanu zaspokojenia potrzeb. Studia Regionalne i Lokalne, 6(19): 45-64. 
ŚLESZYŃSKI, P. (2006): Suburbanization processes in Poland after 1989. Problems of Geography, 1-2(2006): 105-117.

ŚLESZYŃSKI, P. (2013): Demographic change in the functional urban areas in Poland, 2000-2010. Geographia Polonica, 86(2): 169-170.

ŚLESZYŃSKI, P. (2014): Distribution of population density in Polish towns and cities. Geographia Polonica, 87(1): 61-75.

SZELENYI, I., ANDRUSZ, G., HARLOE, M. (1996). Cities after socialism. Urban and regional change and conflict in. Oxford, Blackwell

TAMMARU, T. (2001): Suburban Growth and Suburbanization under Central Planning: The Case of Soviet Estonia, Urban Studies, 38(8): 1341-1357.

TALEN, E. (2014): Urban and regional sustainability. In: Fischer, M. M., Nijkamp, P. [eds.]: Handbook of Regional Science (pp. 1071-1083). Berlin, Springer.

TIMAR, J., VARADI, M. (2001): The uneven development of suburbanization during transition in Hungary. European Urban and Regional Studies, 8(4): 349-360.

TOSICS, I. (2006). Spatial restructuring in post-socialist Budapest. In: Tsenkova, S., Nedovic-Budic, Z. [eds.]: The Urban Mosaic of Post-Socialist Europe (pp. 131-150). Dordrecht, Springer.
TWARDZIK, M., HALAMA, A. (2017): Dostępność usług handlowych w obszarach suburbanizacji na przykładzie południowych dzielnic Katowic. Studia Ekonomiczne, 316: 183-196.

WECŁAWOWICZ, G. (1997): The changing socio-spatial patterns in Polish cities. In: Kovács, Z., Wießner, R. [eds.]: Prozesse und Perspektiven der Stadtentwicklung in Ostmitteleuropa (pp. 75-81). Passau, Verlag.

WHITEHAND, J. W. R., CARR, C. M. H. (2001): Twentiethcentury suburbs: A morphological approach. London, New York, Routledge.

WIECHMANN, T. (2008): Strategic flexibility beyond growth and shrinkage: Lessons from Dresden, Germany. In: Rugare, S., Schwarz, T. [eds.]: Cities Growing Smaller (pp. 19-29). Kent State University, Cleveland Urban Design Collaborative.

ZEBBIK, G. (2011). Typology of suburban communities in Poland. Bulletin of Geography. Socio-economic series, 16: $173-188$.

\section{Please cite this article as:}

SZMYTKIE, R. (2021): Suburbanisation processes within and outside the city: The development of intra-urban suburbs in Wrocław, Poland. Moravian Geographical Reports, 29(2): 149-165. doi: https://doi.org/10.2478/mgr-2021-0012 